\title{
El nuevo orden económico mundial y los elementos básicos para una estrategia nacional de desarrollo en El Salvador
}

\begin{abstract}
Carlos Umaña
Introducción

La economia mundial está en transición hacia un nuevo orden, hacia una nueva estructura global. Se ha translormado la base técnica de la producción mundial, el aparato productivo y la esıructura de la matriz insumo/producto mundial, y se está conformando una nueva división Internacional del trabajo. Se están redefiniendo las relaciones entre las diferentes'naciones y están cambiando las formas de los diferentes estados así como el ámbito y amplitud de injerencia y acción. Asimismo, están cambiando las relaciones (estructuras) inter-estalales y las diferentes instancias institucionales mundiales que las representan. También están cambiando las formas de pensamiento, las Ciencias Sociales, las ideologías y los estilos de vida en su colidianeidad. Realmente, eslá surgiendo un nuevo bloque histórico mundial en loda la extensión de la palabra.
\end{abstract}

Según la perspecliva del observador, el cambio puede parecer realizarse en la dirección adecuada o no, con la amplitud esperada o no, pero más allá de cualquier consideración ética o política sobre la naturaleza de este nuevo orden, el hecho es que es una realidad.

El Salvador, como parte de esle mundo, se encuentra lambién en 
transición entre dos épocas de su historia nacional. La transición del pais no es producto de la transición mundial, ni una respuesta adaptaliva a ella, ni un fenómeno aislado o aparte; tampoco es una coincidencia hislórica con esa transición mundial. Más bien, la crisis y transición salvadorefia es la forma particular a nueslro pais de cómo se realizan los grandes cambios mundiales, en cuanlo que El Salvador está dentro conformando parte de esa economia mundial. En este sentido, la economía mundial no es un enle hipostasiado, abstracto, por encima de las economías nacionales. Más bien, es su tolalidad concreta que se realiza por medio de realidades particulares como la nuestra, en unión con todas las economías nacionales.

El nuevo orden económico mundial implica una nueva división internacional del trabajo, una nueva estructura comercial y tinanciera, así como cambios vectoriales de sus flujos en cuanto a magnitud y dirección. En consecuencia, al margen de la consciencia que en el pais tengan las fuerzas sociales al respeclo, implicará necesariamente una nueva posición o ubicación del país en ese nuevo orden. Tomando en cuenta el nivel de conciencia, la simplicidad y lo tardio de las propuestas provenientes de las fuerzas sociales salvadorefias, hasta ahora un escenario sombrío y pesimista se puede preveer para el pais en el cual éste pierde y desmejora aún más su posición relativa en ese nuevo orden económico.

Sin embargo, los acuerdos de paz y la finalización del confliclo, los cambios en proceso, asi como el precedente de nuevos métodos de resolución de las contradicciones entre las dilerentes fuerzas salvadorehas, ofrecen la posibilidad de un escenario dilerente. El escenario mundial se eslá contormando y dentro de este marco láctico dependerá de la capacidad, inteligencia y madurez política de los salvadoreños el posibilitar un mejor ubicación relativa en esa nueva estruclura económica mundial.

En principio, para que eso sea posible es necesario que exista en las diferentes fuerzas sociales conciencia por un lado sobre la envergadura, en cuanto profundidad y extensión de los actuales cambios mundiales, y por otro del significado histórico de la actual crisis en la historia y el desarrollo nacional. Esta toma de conciencia requiere ir acompafiada de un nuevo esquema mental del desarrollo, para superar los viejos esquemas de los setenta y más atrás sobre las estralegias del desarrollo, tanto en su forma neoliberal como en su vertiente estrucluralista/dependencista. En esla perspectiva, será lambién importante la capacidad de imaginación y visualización hacia el futuro, para que sea éste, con sus desafíos, el que una a los salvadoreños. La capacidad de las diferentes 
clases sociales, de los partidos políticos, de las diferentes inslituciones de investigación y desarrollo, de las universidades, elc., tendrá en el futuro inmediato el gran examen de la historia. En la ausencia de respuestas o talla de estuerzo serio, no habrá excusa para nadie.

La guerra, que se ha constituido en la etapa más dolorosa de loda la historia del pais, aparentemente ha terminado. Sin embargo, no hay crisis, por profunda que sea, que los hombres inteligentes no la puedan convertir en una gran lección que polencialice su desarrollo futuro. Por eso mismo, la experiencia dolorosa de la guerra puede ser el precedente de una nueva práclica social que eleve a todos los sectores sociales por sobre las diferencias, los rencores y pasiones del pasado y los una en el futuro por sobre la mediocridad y mezquindad de los intereses inmediatos y cotidianos. Esto podrá parecer difícil y romántico, pero asi siempre han parecido los grandes desafios y relos históricos; han sido los grandes desaflos del futuro los que han unido pueblos.

Con este espiritu es que el presente trabajo pretende idenlificar cuáles son los cambios en las relaciones lécnicas y económicas que se están desarrollando en la economía mundial, cuáles son sus tendencias y caracteristicas más sobresalieptes y cómo condiciona o qué implicaciones tiene para nuestros paises esla nueva estruclura mundial. Sobre esta base, persigue determinar cuáles podrian ser las tareas estratégicas o ejes de acción de consenso para el pais en esle contexto mundial, que permitan un reinserción conveniente. Es decir se proponen las bases de una polílica industrial orientada a la reestructuración productiva en función de construir un nuevo proceso de desarrollo

No es el temor a la equivocación lo que debe limilar la capacidad heuristica; después de todo, existe el consuelo de lo hislórico de cada obra y que cada hombre es hijo de su época. En los momentos y requerimientos actuales, no es la formalidad y la pulcrilud retórica la necesaria. Más bien, lo que se requiere es ensayar nuevas rulas, proponer nuevos caminos, experimentar y desarrollar ideas inéditas, ampliar y redefinir conceptos. En el campo inlelectual, eslo es cubierto por el ensayo, que permile adelantar contenidos sin la preocupación obsesa de los límiles del significante, y sobre ésle caminar, ir haciendo camino. Implica una actilud abierta hacia diferenles y nuevas ideas y el reconocimiento que los conceplos mismos enlrentan su propio movimienlo hisıórico, es decir que ellos están sujelos a un proceso de desarrollo. 


\section{El fin de un periodo histórico y el nuevo orden mundlal}

\subsection{El tin de un periodo mundial.}

En una de sus últimas visitas a Europa Occidental (Francia), aún como primer mandatario de la URSS, Gorvachev anunciaba el final de la post guerra, la conclusión de la guerra fria, haciendo un llamado a consIruir una nueva era. El uso del término post guerra, ha tenido el propósito de identificar un período histórico específico en función de la misma guerra, el cual trazó el bosquejo de su configuración poslerior a partir del conflicto o crisis en su origen. Estaba recién dernumbado el muro de Berlín, la unificación alemana se veía como una realidad y toda Europa oriental se eslaba transformando. Era obvio a la percepción mundial que un viejo mundo estaba terminando y otro nuevo eslaba surgiendo. A partir de semejantes evenlos históricos, la poslerior desintegración de la URSS y el surgimiento de la CEI, nadie necesitaba solislicados indicadores para tener la cerleza sobre los cambios mundiales.

Sin embargo, la certeza del cambio mundial es muy diferenle a la conciencia real del cambio. La forma de aparecer de los fenómenos proporciona a la conciencia común, por medio de lo obvio, una ocultación inmediala de la verdad. $Y$ esto es precisamente lo que está ocurriendo con respecto a la dinámica mundial de conjunto a partir de los cambios del Este europeo.

Parecería que el sislema de libre mercado y la democracia representativa al estilo occidental se exlenderán por el globo. Los cambios se presentan como el triunio de un sector y de un sislema económico y su extensión al orbe terreno; el cambio se presenta y se prelende explicar por absorción o extensión. Cambia el todo porque una de las partes aparentemenle ha desaparecido en su peculiaridad al ser absorbida por la otra.

Con la segunda guerra mundial linalizó un período económico y se inauguró uno nuevo. Asimismo finalizó la intersección de dos periodos; una especie de subperiodo de transición, que cubre a partir de la primera guerra y la revolución de oclubre hasta la finalización de la segunda guerra en 1945. Este subperíodo de Iransición se caracterizó por ser uno de los momentos de mayor inestabilidad económica y política en la economía mundial. Duranle éste se experimenlaron, como ahora, grandes depresiones y desajustes económicos intemacionales, y surgieron y se desarrollaron fenómenos y convulsiones de orden político.

En perspectiva, con la primera guerra mundial no se definió 
cualitativamente un nuevo orden económico. Más bien se reafirmó en cierto sentido el anterior, pero a la vez si se inauguró la transición entre dos épocas. Se prolongó el orden económico anterior porque no se resolvieron las contradicciones inherentes a lo que en historia económica se llama la era de los imperialismos tormales o colonialismo, ni se logró definir una nueva estructura mundial. Este papel le correspondió a la segunda guerra mundial. Al finalizar ésta, ya estaba en marcha el marco institucional económico del nuevo período histórico, con Breton Woods; la nueva instilucionalidad económica, con el GATT, el FMI y el BIRF y la nueva configuración geopolílica mundial, a partir de los Acuerdos de Yalta. A partir de alli, se pertilaron los dos grandes bloques económicos mundiales. Los intentos de Inglaterra y Francia por restaurar el antiguo orden económico colonial en Alrica y Asia, se enfrentaron con un movimiento descolonizador que se habia desarrollado en el Tercer Mundo a lo largo del período de transición; que se había nutrido ideológicamenle con la Revolución de Oclubre; que había madurado económicamenle con la gran depresión, y habia adquirido consistencia e independencia política durante su desconexión con los centros coloniales en los ańos de la Segunda Guerra Mundial.

Las antiguas polencias nunca recuperarian su papel estelar mundial. Para la década de los sesenla se derrumba definilivamente la forma colonial de comercio y de dominación mundial, cambiando drásticamenle el mapa político y económico y la lorma de hacer política mundial. Se reeditan los atlas y almanaques geográticos mundiales para actualizar los cambios en relación a la siluación de las décadas precedentes.

Los inicios y el surgimiento (1918-1945) del periodo que actualmente está terminando (1945-1992) ilustran claramente la dinámica mundial subyacenle entre periodos, que va más allá de la especificidad hislórica de cada momento. Aquel momento de Iransición mundial (1918-45) y sus particularidades ayudan a comprender la elapa de transición actual (1973-9?), hacia un nuevo orden mundial.

El entrecruzamienlo de las líneas de vida de lo viejo con lo nuevo, de los periodos, órdenes y bloques mundiales, marca la peculiaridad de momentos de transición como el presente:

a) Enlra en crisis y no ha terminado el anterior orden económico mundial y de sus entrañas va surgiendo uno nuevo:

b) La implantación del nuevo no significa más que el final de la transición, no la desaparición del viejo;

c) El desarrollo y consolidación del nuevo está acompañado de 
reediciones parciales del viejo, prolongandose en el tiempo al inlerior del nuevo período;

d) Pero esta prolongación liene un nuevo peso y significado. Redimensiona los viejos aclores, naciones, clases sociales y conflictos, matizando y jerarquizádolos en función de la nueva dinámica y particularidad de la pujante nueva estructura mundial;

e) La nueva estructura y orden económico mundial no se definen a partir de las fuerzas económicas en pugna que maduran con el periodo y estuvieron en el inicio de la crisis, sino más bien con las que terminaron el confliclo, que pueden ser olras fuerzas secundarias o las mismas aparenlemente, pero realmente transfiguradas. En este sentido, el nuevo orden económico no es la prolongación o exlensión al adversario de la particularidad económica y política de la fuerza triunfante, sino más bien la superación de ambos contendienles.

f) Toda crisis no es una mera crisis en absıracto, sino más bien una Iransición con un significado y papel económico e hisiórico a desempehar y limilaciones y conflictos a resolver. La comprensión del significado por lo general es posible hasta agotarse el papel histórico del periodo al cual dió origen.

Esto permite identificar el presente como una nueva transición, la crisis económica mundial desde 1973 al presente, como pasaje histórico de lo viejo no terminado, a lo nuevo no claramente definido ni consolidado.

La unificación alemana y el desmoronamiento como bloque económico de los paises del CAME , podrian ser considerados los hitos históricos que marcan el final de la transición. Sin embargo, esto sería falla de prudencia en la interpretación hislórica, debido a las grandes ineslabilidades mundiales representadas en los significativos desajustes del comercio internacional. No se vislumbra aún la definición, ni mucho menos la consolidación, de un nuevo orden.

Adicionalmente, se prevé un movimiento pendular de restauración o de reconfiguración del Este europeo, o bloque socialista, para dentro de unos pocos años. Siempre despues de un periodo de revolución y negación social, viene un periodo de restauración y alirmación. Esta indefinición histórica del nuevo orden económico es lo que provoca una prolongación de la transición por medio de crisis recurrentes en diferentes espacios geográficos mundiales. Incluso pareceria que se podrlan avecinar aún mayores cambios. A dilerencia de lo que se podría creer, los acontecimientos y cambios en Europa del Este no han terminado; signos de restauración empiezan a surgir; los cambios en Europa Occi- 
dental están comenzando y las grandes contradicciones acumuladas del comercio inlemacional (entre los países de la OCDE) aún no logran resolverse. Todavía no aparece claramente definido a la conciencia de los analistas, ese mundo nuevo del que tanto se habla. Sin embargo, en el mundo real del quehacer económico, lodos se están preparando en función de ese nuevo orden.

Después de la segunda guerra mundial, la economía mundial superó la lorma y periodo hislórico precedente no exlendiéndolo ni derrumbádolo, sino negádolo por medio de las nuevas tormas, de un nuevo orden económico mundial. A partir de 1945 se pasó de la dominación e integración formal, a la articulación económica real. El intercambio y la relación insumos/productos a nivel mundial ya no se viabilizaría o canalizaria por el conduclo del ejercicio de la dominación y del poder militar y polílico, sino que por la necesidad económica. Un determinado espacio geográfico ya no se integraba al mundo bajo la forma de colonia como proveedor de materias primas y como mercado de medios de consumo, sino como unidad articulada económicamente dentro de una división internacional jerarquizada de producción y consumo, traspasada por unidades empresariales transnacionales de producción, tal como una relación matricial organizacional. A lalta de nuevos conceptos se ocuparon los anteriores; se hablaba de Neoimperialismo, Neocolonialismo, Imperialismo Real.

La necesaria negación de los grandes bloques económicos coloniales adquirió la forma de una plétora de naciones en Africa y Asia. Esto afirmaba un nuevo marco o espacio de desarrollo para las nuevas unidades productivas transnacionales. Las compańias Iransnacionales no eran la continuación de las grandes compańías monopólicas del período anterior, sino que realmente conslituyeron su superación tanto por el espacio de desenvolvimiento y concurrencia, como por su organización administrativa y forma de operar.

Por olra parte, al observar el linal de la inslitucionalidad politica y económica del nuevo período (1945-92) se puede comprender la dimensión de ésle como superación del anterior (1890-1945): la construcción de un verdadero sistema financiero internacional, de un acuerdo de comercio que posibilitó un llujo internacional de bienes y servicios relalivamente libre, la articulación producliva por las transnacionales, la diversidad de naciones como negación de la unidad colonial, trasnacionales vrs monopolios, elc. Entre ambos períodos existió una conlinuidad y diferencia. La diferencia esencial entre ellos radica en lo mismo que constituye el eje de su continuidad porque entre cada periodo hay una frontera que delimita su particularidad y necesidad histórica y a la vez una continuidad 
de desenvolvimiento entre ellos.

El período del colonialismo se caracteriza por la subordinación direcla, pero formal, de la producción mundial a los centros económicos y la introducción de las relaciones asalariadas en las colonias, especialmente en las ramas extractivas y agropecuarias. La formalidad económica del proceso de producción se da precisamente por su base técnica manual. Las relaciones asalariadas formales (no mecanizadas) de la producción, es decir, la producción manual será la nota característica del período en la perileria en su vinculación a la estructura productiva mundial. El nuevo periodo, en cambio, mecanizará las dos antiguas ramas e industrializará la producción de medios de consumo destruyendo o restringiendo su base artesanal a nivel mundial. Asi desarrolla y adiciona una nueva articulación mundial de ramas y paises por medio de la ampliación de la producción de maquinaria, equipo y maleriales químicos, e industrias de consumo en la perileria.

La industrialización de ramas de consumo en la periteria es una necesidad para cada pais y lambién para el nivel de desarrollo de la producción mundial de equipo y maquinaria. Esla necesidad histórica aparecia a los técnicos del desarrollo en Latinoamérica como estralegia nacional e independienle de desarrollo vía sustitución de importaciones. La lógica económica mundial era congruenle y se presentaba como lógica del capital nacional, apareciendo como necesidad propia de "independencia" y de desarrollo.

En esto precisamente radica la naturaleza y continuidad de la integración real del nuevo período, en que el impulso para el desarrollo del capital mundial no es impuesto a la periferia como algo externo, sino es vislo y asumido como necesidad propia por el resto del mundo, aunque responde simultáneamente a la necesidad de crear un gran mercado de equipos y maquinarias a nivel mundial y a la de prolundizar las relaciones asalariadas en los paises del Tercer Mundo.

En el orden mundial que actualmenle eslá finalizando se puede derivar su principal característica del papel histórico que cumplió en el desarrollo del capitalismo a nivel mundial. En función del anterior periodo, cumple la función de establecer de forma real una arliculación de relaciones asalariadas a nivel mundial como forma dominante de la producción mundial. Posteriormenle a las guerras mundiales, se asiste a un nuevo orden mundial y a una particular articulación administrativa matricial en las relaciones entre capitalismo de Estado y empresa Iransnacional. Por articulación real se entienden las lormas asalariadas y las caracterlsticas devenientes de la producción industrial sobre la manual; lo cual no significa la existencia de unas cuantas unidades al inlerior de los paises 
periféricos, sino la existencia de una relación de producción socialmente dominante en la producción global. En el periodo previo a las guerras mundiales, se asistio a la articulación y dominación formal.

Como base de la transformación mundial, en éste último período se encontraban los cambios lécnicos y de organización y operación administrativa de las empresas que significaron las dos guerras. Se dieron cambios de aplicación técnica de la mecánica, la química, la biología, la informálica, la aerodinámica, la electrónica, etc. Las ciencias y la política económica, es decir, la forma de intervenir o regular la economia por parte del Estado, se ven dominadas a partir de la segunda guerra por el pensamiento keynesiano, desplazando al pensamiento neoclásico. Se desarrolla un instrumental técnico-económico para regular el crecimiento económico vía afectación de la demanda y la coniormación de una teoría del desarrollo marcada por la industrialización y la individualidad nacional. Los instrumentos y conceptos microeconómicos desarrollados dentro del pensamiento neoclásico para afectar la oferta, es decir para afectar la estructura de la.producción, son colocados en un segundo plano.

Solamente al final del periodo económico, en la década de los selenta, se está produciendo una sintesis leórica. Al entrar en crisis la economla mundial, en occidenle también entran en crisis los conceptos e intrumentos de política económica de corte keynesiano orientados a la afectación de la demanda. De nuevo se están redescubriendo los instrumentos de afectación de la olerta, de la producción, muy vinculados a aulores neoclásicos (y paralelamente y conlundido con ello, se está produciendo el resurgimiento del neoliberalismo). En el Este europeo se está produciendo el fenómeno contrario: se están abandonando los instrumentos socialistas de planificación centralizada, de orientación de la oferta y estructuración de la producción, por un excesivo, y hasta ingenuo, cullo a la demanda.

\subsection{El nuevo orden económlco mundlal}

\subsubsection{La contormación de la nueva base técnica.}

Al interior de cada período conslantemente se desarrollan nuevos procedimientos y productos, dentro de una marco técnico especitico que contribuye a su conformación, desarrollo o consolidación. Sobre este marco o base técnica más o menos estable y delinida, es que se contorma una más o menos delinida proporcionalidad especifica en cuanto volumen material de la planta producliva y del producto anual entre todas las ramas dentro del bloque económico de ramas y paises.

A diterencia de lo anterior, lo que hemos presenciado en los últimos 
veinte años (73-92) no es innovación y desarrollo secundario, sino más bien una revolución tecnológica que ha conducido a una transformación de la antigua base lécnica y a la creación de una nueva y en consecuencia a un cambio del contenido material de la producción, en cuanto a insumos, instrumentos de producción y medios y servicios de consumo humano.

A este cambio malerial real, en cuanto composición del producto y de la estructura técnico-productiva, es lo que en términos concrelos denominamos cambio de calidad del sistema productivo mundial, lo cual se distingue de los cambios e innovaciones graduales, o cuantitativas, al interior de un período histórico, que conducen a su mejoramiento o completo despliegue, más no al cambio de los principios técnicos y el sustralo material en los cuales se fundamentan.

Los cambios actuales han alectado cada una de las tres subestrucluras técnicas en particular y su engranaje. La subestruclura físico/mecánica básicamente con las innovaciones en la manipulación del electrón (microeleclróniç), especialmente como soporte en lo aplicable a la inlormálica; en la subestruclura química fundamentalmente con el desarrollo de nuevos maleriales y aleaciones (por ejemplo el silicón semiconduclores), y en la biológica, con las nuevas formas de tecnobiologia en cuanto a ingenieria genética vegetal y animal. A estas nuevas condiciones materiales de las subestructuras técnicas, se plantea en adición como una nueva subestructura y como producto específico, desarrollado de la actual trasformación tecnológica, los procesos técnicos masivos de la informática y una de las industrias más dinámicas como es la del software en los últimos años..

\subsubsection{La conformaclón de una nueva estructura, forma materlal y distribuclón espaclal del aparato productlvo mundlal}

Alendiendo a estos cambios técnicos y de la base malerial, se ha conligurado una nueva estructura jerárquica entre las ramas o partes del aparato productivo, de la eslruclura del producto, dando lugar a un nuevo cuerpo malerial del aparato mundial de producción y en consecuencia, a una nueva dislribución espacial. La nueva contormación material planlea, lógicamenle, nuevas necesidades de volumen e imporlancia jerárquica de los insumos y los productos, dando origen, a la vez, a una nueva esinuctura y contenido material de la matriz insumo-producto mundial.

En este sentido, la nueva configuración material y de volumen del aparato productivo, determina la forma y estruclura del producto material, la matriz insumo-produclo mundial y su distribución espacial en la 
geografía mundial. El desarrollo del aparato produclivo es el que determina los produclos que son necesarios para su propia reproducción, $y$, en ese sentido, el florecimiento y decadencia de áreas o paises donde se encuentran lales produclos.

\subsubsection{Cambios del sistema mundlal de valor}

El cambio de la base técnica implica la revolución del sistema mundial de valor, la Iranstormación de las relaciones de valor como sistema mundial ( $y$ del sistema de precios obviamente), expresada entre olras lormas, a lravés de la transformación de los términos de intercambio. La conmoción del mismo fundamenlo, transiorma las unidades de medida, es decir, los parámetros históricos de cómo se relaciona o representa en valor una unidad material: cambia la unidad entre estructura técnico material y estructura de valor.

Los cambios en las unidades de valor en periodos de transición no expresan con certeza o han dejado de ser representativos de los cambios de las unidades materiales, distorsionando o velando (cubriendo), la magnilud y dirección de estos cambios de la base malerial; a veces ocullando el colapso de la vieja estructura material y el surgimiento de la nueva. Así, se impone como necesidad un nuevo sistema de valor y, en concordancia, un nuevo sistema de indicadores de medidas del desarrollo, en aras de una mejor comprensión de estos cambios y de la nueva estruclura. La revolución del sistema de valor implica nuevas relaciones o razones de equilibrio en la reproducción global del aparalo productivo. Las nuevas lasas podrán ser diferentes a las anteriores, pero lo impor: tante a identificar es que se establecen nuevos equilibrios cuantitalivos Iransformando los parámetros en los modelos malemálicos de crecimien10, estableciendo nuevas razones y proporciones asi como nuevas escalas de magniludes absolutas para medir el producto global.

\subsubsection{Cambios en las estructura económlca administratlva}

Como estruclura económica mundial se entiende las múltiples relaciones en el proceso produclivo que se establecen entre los hombres para la generación del producto mundial (incluyendo las relaciones de intercambio y dislribución). En principio, esto implica la relación obrero/patronal, pero, además las relaciones técnicas de interconexión entre todos los trabajadores en cuanto a la generación del producto global, a la relación cuantitativa proporcional y la distribución de la fuerza de Irabajo entre las diferenles ramas de la planta productiva mundial en los diferen- 
tes palses y su participación en la generación y distribución del producto global. La estruclura económica debe entenderse, en primera inslancia, como la estructura o la conformación de la planta productiva, es decir, debe entenderse como el peso que tiene el patrimonio de cada rama dentro del conjunto de la planta productiva, tanto en cuanto a medios de producción como a luerza de trabajo. En segunda inslancia, debe entenderse como la estruclura, interconexión y composición del producto global generado es decir la matriz de insumo/produclo.

El análisis del cambio en la esıructura de la planta productiva implicaría un conocimiento de la estructura del patrimonio mundial o riqueza mundial. Adicionalmente, requeriria conocimiento de la estructura del producto mundial, es decir, de la matriz insumo/producto mundial, que implica el conocimiento de su función lécnica y su estructura de valor en cantidades absolutas y relalivas.

Para estudiar los cambios en la planta productiva a nivel mundial no exislen indicadores sino para el producto mundial. La composición del producto mundial sirve de relerente para el estudio de la planta productiva. Pero para el estudio del cambio del producto mundial se utiliza información sobre los cambios que al interior de cada nación eslán ocurriendo en la estructura de los productos nacionales.

Tradicionalmenle se ocupaba el valor y proporción del producto indusIrial dentro del producto total y su lasa de incremento como indicadores del nivel de desarrollo o de su velocidad u orientación así como del consumo y producción de delerminados maleriales (loneladas de acero - hierro por habilante). Sin embargo, en la actualidad, atendiendo a estos indicadores, los paises tradicionalmente desarrollados entrentan procesos de desindustrialización, o terciarización (secior terciario), y los NIC o paises semiperitéricos, ofrecen mayores índices (Taiwán y Corea del Sur) del producto industrial que por ejemplo los EEUU.

La industria como proporción del PIB ha aumentado sustancialmente en la gran mayoría de las naciones del Tercer Mundo, no sólo en términos absolulos sino también en términos relativos, respeclo a la de los países centrales. A finales de los años 70, los NIC's en su conjunto, no sólo alcanzaron a los países centrales sino además los superaron en términos de sus grado de industrialización.

En 1986, todos los NIC's de Latinoamérica y el Sudeste Asiático, con la excepción de Hong Kong, tenian una relación industria/PIB que excedia el nivel industrial promedio de $35 \%$ de los paises industrializados con economía de mercado. El mismo patrón es válido para la manufactura, que es generalmente la parte más dinámica del seclor industrial. La relación manulactura/PIB en1986 para los Estados Unidos, por ejemplo, fue $20 \%$, que es, más baja que la de cualquiera de los siete NIC's de Latinoamérica y el Sudeste Asiático. 
Mientras la industria y la manulactura como proporción del PIB están en decadencia en las naciones más desarrolladas de la economía mundial, esta tendencia es compensada por el énlasis de los países cenlrales en el sector servicios, y en los segmenios de la manufactura más productivo y de mayor valor agregado. Irónicamente, a medida que más y más países en el mundo se están industrializando, la industrialización a sí misma está perdiendo el papel clave que una vez tuvo como indicador delinitivo del desarrollo nacional.

Estas observaciones conducen a dos conclusiones básicas acerca del status teórico de la industrialización en la economía mundial contemporánea. Primero, "industrialización" y "desarrollo" no son sinónimos. Esto se relleja en las consecuencias sociales y económicas del crecimiento industrial en los NIC's de Lalinoamérica y el Sudesle Asiático en el último par de décadas. A pesar de que los altos niveles de industrialización son similares en los NIC's de ambas regiones, las naciones del Sudeste Asiático se han desempeñado signilicativamente mejor que sus homólogos latinoamericanas, en términos de los indicadores estándares de desarrollo, tales como PNB per cápita, distribución del ingreso, alfabetismo, salud y educación.

Segundo, así como la industrialización no es sinónimo de desarrollo, tampoco garantiza la proximidad al status central en el sistema mundial. A pesar de que los NIC's son ahora más industrializados que muchos países centrales, este logro generalmente no conduce a un cambio sustancial en la posición relativa de los NIC's en la jerarquia de las naciones de la economía mundial. (Porles y Kincaid, pp. 75-77 1990).

Con esto se asiste a la identilicación de varios fenómenos actuales:

- Los límiles de la necesidad de la producción malerial industrial. La producción industrial ya no crece indefinidamente, sino que es proporcionạl al cuerpo produclivo global, a la necesidad de reproducción material. Alcanzado un cierto nivel, son otros sectores los que expresan un mayor dinamismo y las tasas incrementales de producción material industrial pueden volverse negativas, ante incrementos drásticos de productividad y eliciencia de insumos y reciclajes.

- Cambio en la jerarquía entre ramas. Se desarrollan ramas que se convierten en las estratégicas y ofrecen mejor rentabilidad, reservándose tendencialmenle para los paises centrales aquellas que se constituirian en el centro de comando, el sistema nervioso y el espinazo, del aparato productivo. En el espacio geográfico mundial, se produce una relocalización en dirección hacia la periferia, de aquellas ramas que si bien fueron estratégicas en el anterior periodo hoy ocupan un lugar secundario (siderúrgica, petroquímica, etc.), encontrándose dentro de estas aquellas de producción industrial con efectos graves para el ecosistema.

- Reagrupación funcional real enlre ramas. El surgimienlo de nuevos productos y nuevos procedimientos, así como la desaparición de otros y 
la interrelación insumo-producto entre todas, ha provocado un deslase entre la estructura conceplual de aprehensión del aparato productivo (CIIU) en cuanto a las clasificaciones o agrupaciones tradicionales y el mismo aparalo produclivo, produciéndose incongruencias entre conceplo y ser material.

En resumen, se asisle a una transformación defla planta producliva material y, en consecuencia, de la matriz mundial insumo produclo, que trae consecuencias directas en la ubicación de cada pais: i) Una nueva composición material de los tipos de productos y de su planta productiva para cada una de las ramas con las consecuencias en las balanzas comerciales para las naciones productoras de esos viejos y nuevos produclos; ii) Cambios de las jerarquias entre las ramas en cuanto a preeminencia y volumen de valor; iii) Cambios en la interrelación insumo producto enlre ramas.

Estos cambios económicos, es decir, en la relación entre los agentes económicos, se traducen en cambios en las estructuras administrativas de las unidades empresariales. Estos cambios llevan necesariamente a una redefinición en las unidades produclivas empresariales en cuanto al tamafio y localización óptima de la unidad producliva; recontormación de la organización y funcionamiento de las empresas cambios en los mélodos y estilos de administración empresarial; en las formas de propiedad; en la forma de interrelación entre unidades produclivas, en cuanto al engranaje productivo y la estructura administrativa, local e internacional.

Eslo se puede apreciar en la nueva conformación técnico/adminisırativa de las multinacionales. Las nuevas formas no son de grandes empresas con sucursales o subsidiarias en los paises del mundo, que orientan la producción o la prestación de servicios hacia los mercados internos de los paises sedes. Más bien, presenciamos diferentes ubicaciones aprovechando venlajas de localización especílica, ya sea de recursos nalurales, humanos, infraeslructurales, seguridad elc., en función del mercado mundial o de otros paises específicos.

En las empresas de vanguardia está siendo relegada la orienlación al desarrollo de grandes planlas o companias productoras de todos los componentes de un producto y que controlaban horizontal y verticalmente lodas las diterentes fases del proceso produclivo y distribulivo. En la actualidad asistimos a un entrelejido malricial empresarial, dilerenciandose entre empresas integradoras de dilerentes elementos de un producto y empresas especializadas productoras de elemenlos especificos para diferentes compañias inlegradoras de diferentes produclos. Las companías integradoras no son las viejas plantas ensambladoras sino 
aquellas que controlan las lases eslratégicas en las que se unen diferentes componentes con la mayor rentabilidad.

Esto se traduce a la relación companía transnacional/ocal, en la cuales la primera controla los procesos de mayor rentabilidad o las fases que permilen el control estratégico de dirección de conjunto, y las segundas los procesos más gruesos y/o menos rentables y subordinados.

\subsubsection{Cambios en la relación económica Internacional y los flujos humanos, materlales, financleros e Informaticos.}

Cada momento de desarrollo de la producción se viabiliza o desenvuelve por medio de la estruclura internacional transformándola y translormandose muluamente. El cambio técnico-material de la producción mundial en su dirección de innovación está condicionado por los intereses de naciones y grupos sociales; asi la nueva base técnica no se conforma en abstracto, sino en correspondencia a determinados intereses de grupos y jerarquia de naciones.

En la fase actual de transición, se está creando una nueva división internacional del trabajo (es decir cómo se distribuyen las ramas mundiales en el espacio geográfico internacional). De nuevo, se da la condicionante de la necesidad producliva material mundial, diferenciando el comportamienlo de las industrias agricolas y exlractivas, que son las que proporcionan la base material de la pirámide productiva de las subsiguientes que otrecen un mayor grado de movilidad espacial.

El término, relocalización de industrias, dentro de este contexlo de una nueva división internacional de la producción, tiene el peligro de connolar únicamente desplazamiento geográfico, y no informa de su desplazamiento jerárquico como ramas de mayor rentabilidad y valor esıratégico ni de su cambio funcional en cuanto al cambio en la ubicación dentro del engranaje productivo.

En eslo debe considerarse que las necesidades y funciones productivas no son un universo infinilo, más bien se dan en un espacio limitado. linito, para un periodo determinado. Es decir, el mercado mundial no es una bolsa con un vacio infinilo. El espacio de necesidades, o el papel funcional denlro de la producción malerial desempefiado o adquirido por una nación, imposibilita o desplaza el surgimiento de otro, por el espacio finito de posibilidades maleriales.

En esle sentido, el aparecimiento y desarrolio por los paises semiperiféricos (NICs) debe de explicarse dentro de este marco de posi- 
bilidades y necesidades de producción malerial a nivel mundial. La relocalización de industrias hacia esta nueva semiperiferia se imposibilita o dificulta a unas más que a otras. En todo caso, el surgimiento de otros NICs, en el marco anterior hubiera desiquilibrado a los viejos y les disputaria el papel en su ubicación estructural. Con el cambio de la matriz mundial y su relocalización, se abre un periodo de inestabilidad de las ubicaciones nacionales y en consecuencia de una fuerle concurrencia.

Ninguna nación tiene un estatus permanenle; los países asiáticos del extremo oriente desplazaron el papel luncional de semiperilérico y de jerarquia intermedia de ciertos paises latinoamericanos. Si se analiza el desenvolvimiento hisiórico de la región latinoamericana, esto es preocupante. A principios del presenle siglo varios paises de Latinoamérica tenían una ubicación mundial mejor que la mayoría de los paises del mediterráneo (europeos, asiáticos y alricanos) y los del extremo oriente. En la actualidad, la ubicación réleja un desplazamienlo relativo negativo en la eslructura jerárquica como región de lorma signilicativa. El periodo de la posiguerra (45-92) arroja como balance de posiciones un saldo de retrocesos funcionales y jerárquicos para la región.

Si analizamos esle movimiento como tendencia histórica y ubicamos los contendientes históricos de la región, se podrá ver este desplazamiento relalivo en la competencia comercial y la comparación en los estatus de vida de la región: América Latina era comparada a principios de siglo con el sur de Europa, luego con los países extremos asiáticos o con los paises árabes, y actualmente muchos de nuestros países está compitiendo con los paises de Alrica. La máxima antigua sobre que "nada permite de mejor manera informar sobre la eslalura y poder de un combatiente, que la de sus contendientes" se aplica para el caso latinoamericano.

El panorama aclual es de una urgenle carrera y concurrencia entre naciones por la mejor combinación de ramas y niveles técnicos en su inserción en la producción y mercado mundial, que les permita la óplima y más favorable esiructura en los términos de inlercambio.

Todo eslos cambios de relaciones y jerarquias implica un nuevo mapa vectorial, en cuanto flujos de insumos, mercancias, servicios, finacieros( capilales y rentas), migraciones de mano de obra y hasta de turismo, de intormación y de influjos de términos en los idiomas. Como nuevo mapa vectorial, implica cambios de magnitud y dirección de esos flujos. 


\subsubsection{Redefinición de los Estados naclonales y del marco Ins- lltuclonal Internacional}

Si bien se puede identificar una reconfiguración y relocalización de la planta productiva mundial en el espacio nacional se puede presenciar también la redefinición funcional, reconfiguración, redelimilación espacial-geográfica del Eslado nación con respecto a la estructura productiva local e internacional. Es decir, se redefine la malriz productiva mundial y se redefine el mapa geoeconómico y político.

En esto se puede apreciar la descomposición de la vieja estruclura bipolar de bloques económicos inlernacionales y el surgimiento de nuevas lormas de agrupamiento. En esta nuevas articulaciones, alianzas y bloques regionales o particulares, no se puede esperar la reedición de bloques cerrados ni como reedición modernizada de la segmentación de los bloques imperiales, ni de los bloques de la posiguerra. Más bien, 10 que se presencia es una integración más profunda verticalmenle y de una ampliación de los espacios de desenvolmiento. Nos encontramos con procesos integralivos no sólamente de extensión, que es lo más obvio a la conciencia común. La integración es de profundidad, intensidad y exlensión en dos niveles:

- De libre movimiento y desarrollo de la producción del marco nacional al marco regional. Estos espacios de desenvolvimiento mercantiles, como límiles mínimos, son exigidos por la nueva escala de la producción y de la competencia global. Casi ninguna industria europea puede competir con las industrias de los otros bloques en el nuevo periodo con el limilado espacio libre de la vieja esıruclura de naciones.

- De una mayor y más profunda integración del aparalo productivo y del mercado mundial. Es decir, de cómo se eslabonan las diferentes unidades produclivas en la secuencia de elaboración de productos; estamos hablando dentro de la eslera de la producción, dentro de un marco internacional, y de una mayor movilidad de mercancías a nivel mundial, es decir de una mayor integración de la esfera de la circulación a nivel mundial, y en consecuencia de una mayor inlegración financiera.

En este sentido, se identifica una mayor integración como bloques regionales y como economía mundial, más allá de lo exislenle en el presente. En estos bloques regionales y en el nuevo marco internacional, obviamente la función y el papel del Estado-nación se están viendo complelamente modificados, más especialmente en la aplicación de la política económica.

La posibilidad de electividad de cualquier politica se ve actualmente condicionada por el marco regional y, en un sentido más amplio, por el 
nuevo y más sensilivo marco de interacciones entre naciones. En este senlido, afecta de manera muy operaliva la ejecución de planes de gobiemos, teniéndose la necesidad de conformación y cooordinación obligada de dichos planes. Por ejemplo, la conlormación de un mercado común centroamericano puede exigir para su real existencia la coordina- . ción operativa y sincrónica de la polílica monelaria entre los palses integrantes o los programas de inversión en infraesıructura, o el gasto social, etc.

Pero, en términos efectivos y reales, esta coordinación se está produciendo, más allá de las voluntades expresas, como unidad en la acción de la políticas económicas estalales, anle la necesidad de enfrentar problemas particulares de cada nación que son aparentemente individuales y similares. Pero en la realidad es un sólo problema de la economía mundial que lo tienen que enfrentar todas las naciones. Donde se expresa esto con la mayor claridad es en los desequilibrios macroeconómicos de los diferentes paises y las políticas de estabilización y ajuste estructural.

En eslo se ha avanzado de una interpretación superflua del problema y desvinculante de los orígenes de los desequilibrios nacionales, y de una posición maniqueista con respecto al FMI y la deuda externa, hacia una interpretación más comprehensiva, globalista y realisla sobre la necesidad de su solución.

No es coincidencia que se produzcan los mismos males en casi todas las naciones -con la única dilerencia de ser de signos contrarios- 0 se ponga de moda la privatización y la desregulación estatal. EI neoliberalismo se ha pueslo de moda por necesidad histórica de la economía mundial para la transformación del aparalo estalal y la transformación del marco regulalorio. El neoliberalismo no ofrece ninguna interpretación ni alternativas de solución nuevas a los problemas económicos nacionales y mundiales, sino más bien encarna coyunluralmenle las nuevas tendencias mundiales globales.

Adicionalmente a esta desregulación y privatización, se presencia en la aclualidad la formación en un primer momento de estructuras institucionales supraestalales. Sin embargo, lo que realmente se está desarrollando es el crecimiento vertical del aparato estalal y su redimensionamiento.

Las reuniones periódicas de los primeros mandalarios de las principales potencias para coordinar la política económica, o de los presidentes y direclores de los bancos centrales, o las reuniones periódicas de los presidentes centroamericanos, realmente constituyen un nivel de institucionalización orgánica y en esta perspectiva, un crecimiento eslatal 
por medio de la creación real de inslancias de mayor jerarquia vertical. Eslo como ejemplo de inslancias ejecutivas; pero se lienen también instancias legislativas como los parlamentos regionales. Este desarrollo del aparato estatal internacional tiene en forma efectiva niveles superiores de incidencia y relevancia que las instancias multilaterales (internacionales) creadas en el anterior período, como el FMI o las mismas Naciones Unidas. Asi, si bien se presencia una consiricción del Estado en ciertas áreas se ve su crecimienlo en olras, y en este sentido su reestructuración.

Adicionalmente, está en crisis y obsolescencia el viejo marco regulatorio internacional, al ser rebasado por las nuevas inslancias de ejecución y coordinación. La presente crisis de las ONU y el estancamiento de ia ronda del Uruguay, expresan de la mejor manera esta situación. El errático nuevo papel de las ONU como instancia para legitimar la dominación de las relaciones inlernacionales por parte de las potencias nucleares y su intervención en el Tercer Mundo es un ejemplo de los cambios en esta nueva época..

\subsection{Efeclos especificos de los camblos mundiales en el Tercer Mundo}

Todos los paises están arliculados en la eslructura producliva mundial mediados o a través de una división internacional del trabajo. Al cambiar el bloque económico mundial, cambia la forma y contenido de la articulación de productos y ramas de cada país a la producción mundial, produciéndose una rearticulación de ramas y de países. Una nueva estructura de relaciones técnicas de produclos, de insumos en la elaboración de productos, implica simultáneamente una nueva estructura de precios, una nueva estruclura de la planta productiva $y$, sobre esto, un nuevo papel y ubicación luncional de cada país. Cada pais tiene que cambiar la forma y el conlenido de cómo se articula en la nueva estructura mundial.

Es necesario especificar cómo estos cambios afeclan a los países del Tercer Mundo como El Salvador:

a) Los cambios técnicos se pueden expresar como cambios en los insumos en los procedimientos, en los inslrumentos, en los produclos, 0 de la lorma como se interrelacionan todos los elemenlos La dirección y esfera de estos cambios se ubican y se desenvuelven en función de la conlormación del aparato productivo de los paises centrales, o tratando de mantener y absorber las nuevas ramas y desplazando las maduras y menos rentables hacia la periferia. 
Los cambios en cuanto a los insumos implican el desarrollo de nuevos produclos suslitutos $y$ de mayor durabilidad que abaratan o hacen más prescindibles los productos que como insumos vienen del Tercer Mundo (fibra óptica vrs. cobre).

Los cambios en los procedimientos optimizan el uso de las materias primas implican su reciclaje o readecuación de los procedimienlos técnicos en función de bienes sustilulos que existan en los países centrales o en los paises innovadores lécnicamenle.. Implican decremenlos sustantivos en la demanda de los produclos que tradicionalmente producen los paises del Tercer Mundo que en este senlido, registran una lendencia a una sobreolerla y una disminución relativa de los precios. El punto de intersección entre oterta y demanda mundial dinámicamente tiende en forma relativa a desplazarse en detrimento a los intereses del Tercer Mundo.

No cabe duda que la era de la microelectrónica, cuyo nacimiento se sitúa en 1971 , fecha en que se inventó el microprocesador, ya está teniendo un profundo impacto en el empleo de los insumos. De hecho estos extraordinarios avances están aprobado ser ahorradores de capital, mano de obra, materiales y energia (SELA, 1988, p. 207)

En cuanto a los instrumentos de trabajo, los cambios implican innnovaciones sustanciales que hacen rápidamente obsolelos, los instrumentos y maquinarias que se ocupan en el Tercer Mundo en función de la competencia internacional, acortando el desgaste moral o la obsolescencia material.

En cuanto a productos de consumo final, los cambios implican una reorientación de los hábitos de consumo y los estilos de vida. Por ejemplo, se producen casos como la sustitución de hábitos de consumo de cafe, tabaco, huevos, etc.

b) En cuanto a la localización de industrias, 10 más probable es que se asista a la industrialización pesada del Tercer Mundo y al desplazamiento de ramas enteras de bienes de consumo que actualmente se encuentran en los paises centrales. Esto estaria empujando a una nueva modificación del contenido y de los términos del intercambio. En el anterior periodo se industrializó la producción de bienes de consumo del Tercer Mundo orientada al mercado interno y adicionalmente se relocalizaron ciertas industrias de consumo del centro a la periferia.

El advenimiento de nuevas tecnologías y cambios en el proceso de manufactura han llevado a severas dislocaciones en áreas previamente industrializadas y al realineamiento de la estructura productiva global. Las primeras fases del proceso fueron descritas por John Watson en eslos lérminos: 
El capital y la producción son exportados de los palses avanzados desindustrializados para ser colocados en hospitalarias plantas de ensamblaje del tercer mundo, que utilizan mano de obra barata y en plataformas de exportación desde donde los produclos son lanzados a otros palses del centro. Las induslrias de calzado y prendas del noreste de los EEUU, por ejemplo, emigran a México, a Taiwán, en estos dias, también a Sri Lanka, pero los productos hechos por la mano de obra barata de estos palses regresan con lacilidad a la Quinta Avenida o la Calle Principal.'

La literatura más reciente ha documentado una multiplicidad de arreglos a través de los que la producción industrial que emigra es promovida y combinada con innovaciones tecnológicas y manulacluras especializadas en los palses del centro. Más se dirá sobre esle asunto luego. Por el momento el punto es que los términos ulilizados para analizar estos cambios, tales como reestructuración económica o desindustrialización, contradicen la anterior imagen de un proceso de crecimiento lineal. (Portes y Kincaid, 1990, p. 28).

En el nuevo periodo se espera la relocalización mayorilaria de la industria de consumo del centro a la periferia, es decir el proceso inverso al anterior, en el sentido que en América Latina se pretendía sustituir importaciones de consumo de los paises centrales, y en el nuevo periodo veremos más que eso la ubicación de la producción mayoritaria de consumo mundial en el Tercer Mundo.

Asimismo, se relocalizará la industrialización pesada especialmente de aquellas daninas para el ecosistema así como de las induslrias ubicadas en el último eslabón del aparato productivo mundial: Las industrias del reciclaje y de la evacuación de la basura de la producción y el consumo humano, se desplazará del centro hacia la perileria el problema del daño hacia el ecosistema mundial, concentrandose en el centro la función administrativa y de comunicación del aparato productivo mundial asl como de la producción de la industria "del sistema nervioso" mundial, de mayor rentabilidad tecnologica

Para los paises del tercer mundo, este proceso de descentralización representa la oportunidad de una nueva insersión en la economia internacional en un momento en que otras innovaciones tecnológicas amenazaban a sus exportaciones tradicionales con la obsolencia. Los materiales sintéticos y sus derivados han desplazado a los productos minerales tradicionales, mientras que las tecnologlas de reciclaje han reducido grandemente la demanda global de otros. Las nuevas tecnologías en agricultura han incrementado significalivamente la productividad, llevando a mayores excedentes y a una consecuente calda de precios. Como resultado, los paises del Tercer Mundo que continúan dependiendo de las exportaciones Iradicionales han visto sus términos de intercambio deteriorarse dla a dla. En América Latina, por ejemplo, éstos declinaron en un 28\% de 1974 a 1985, al punto en que llegaron a estar solamente un $4 \%$ arriba de lo que estuvieron en el momento de la Gran Depresión. Al mismo tiempo, las oportunidades 
económicas que otrecían las nuevas lecnologías no dejan de tener sus inconvenienles, ni han favorecido a los países del Tercer Mundo uniformemente. Mientras algunos han registrado éxilos especlaculares, otros han visto su industrialización Irenada por estos desarrollos. Aún en aquellas naciones que se han beneficiado más, la industrialización se ha apoyado a menudo en regímenes polílicos represivos y en una distribución desigual de los benelicios. El proceso de reestrucluración económica global a conlribuído a la aparición de nuevas lormas de dependencia y a la familiar paradoja da actores sociales cuya suerle empeora al mismo liempo que crecen sus economías nacionales. (Portes y Kincaid, 1990).

Esta relocalización se presenta o disfraza como nuevas alternativas de producción con respeclo a cada pais o bajo el empaque de productos no tradicionales en cualquiera de las ramas económicas. Asimismo, se pueden dislrazar como imitación de eslrategias de lases de desarrollo de países que pueden en si mismos eslar relocalizando sus industrias. Los paises de Latinoamérica tratando de imilar lases históricas de los NICs, pueden enfrentar la asunción de la relocalización de ciertas planlas que los paises centrales y asiáticos están desplazando.

La relocalización de productos agricolas y de consumo es un fenómeno que actualmenle se está desarrollando con los llamados cultivos no Iradicionales. Recuérdese que los cultivos Iradicionales una vez fueron no Iradicionales, y la absorción de estos y su integración a la matriz nacional de los países del Tercer Mundo no es una estralegia de desarrollo sino más bien un hecho y una necesidad de los paises centrales en su reconfiguración productiva.

Los cultivos no tradicionales, como alguna vez lo fue el algodón en El Salvador, son un círculo vicioso que hace rolar a los paises sobre una misma posición jerárquica. Se dice que se ha puesto de nuevo la agricullura como estrategia del desarrollo (Institulo Interamericano de Ciencias Agricolas IICA), pero esio no hace más que ocultar la dinámica de las ondas históricas de producción en el mapa geoeconómico.

c) En cuanto a los tipos de productos, se puede prever que ningún país escaparán a su reinserción en la estructura productiva mundial, ya sea por acción u omisión, cambiando los porcentajes de participación y en los mercados hacia los cuales van dirigidos. El mejor ejemplo de esto es el caso negativo de completa reinserción aclual de Bolivia. El desarrollo económico mundial eslá conduciendo a volver prescindibles las economias del Tercer Mundo y a hacer decrecer su importancia en el mercado mundial.

A la par de este proceso de disminución de relevancia, se está desarrollando lormas de vinculación que ciertos autores lenoménicamenle 
denominan la "integración perversa", el "cuarto mundo", "el mundo de la informalidad mundial". En esta forma de conexión se está desarrollando formas de vinculación subterráneas que se convierten en rearticulaciones dentro de las relaciones económicas internacionales.

El caso de Bolivia es un caso extremo pero el más aleccionador. Este pais ha visto perdida su arliculación tradicional con la economia mundial por medio de la industria extractiva de minerales y bienes agropecuarios. A partir de las innovaciones tecnológicas, la siluación de Bolivia cambió drásticamente en la década de los ochenlas. Con la caida definitiva y estratégica de los precios del estaño, Bolivia prácticamente se desconeclaba en su imporlancia de la estructura material del aparato pruductivo mundial. A partir de ese momento, sin embargo, se vino desarrollando un nuevo tipo de conexión a través de lo que se ha denominado el complejo productivo agroindustrial de la coca, el cual se ha constiluido en el eje económico sublerráneo del pais y de sus relaciones con el sector exlerno constiluyéndose en la práctica en una nueva forma de reinserción

No hay cálculos conliables, pero el consenso de funcionarios políticos e investigadores estima las exportaciones bolivianas relacionadas con la cocalna a mediados de la década del 80 en alrededor del doble del monto total de exportaciones. Regiones enteras, en particular las regiones tropicales del Chapare, en el Departamento de Cochabamba, pero lambién vaslas áreas de Santa Cruz, Beni y los "Yungas" de la Paz, constituyen las bases para el sistema de producción de coca. Familias campesinas que migraron de los valles y las serranlas deprimidas cultivan las hojas de coca, mientras que algunos de ellos, junto con desocupados urbanos, trabajan en lábricas pequeñas y dispersas que Iranslorman las hojas en pasla base, y la transportan a centros de expedición, desde donde el producto es luego enviado a relinerías colombianas para su venta final en los mercados estadounidenses y europeos. Porles y Kincaid, 1990, p. 123).

Se pueden identificar tres tipos de industrias de alla rentabilidad que se relocalizar en el Tercer Mundo, y que está leniendo ya consecuencias desastrosas: i) la industria de disposición de basura y desechos industriales y tóxicos; ii) la industrias sidenúrgica y quimicas de allo efecto conlaminante, y iii) la industria de producción ilegal de drogas, elevando a escala mundial y ubicando en el Tercer Mundo estas ramas. Las tres se desarrollarán subterráneamente a diferenles niveles e inlormalmente como es el caso de las drogas, produciendo daños sociales de grandes consecuencias.

d) Los países periféricos están jerarquizados en niveles tecnológicos, expresados como tasas medias de composición técnica, y a la vez vinculados a tipos de productos. Entrentan la disyunliva o se desplazan sobre las ramas y niveles, manteniendo la misma posición jerárquica o avan- 
zando en ellas, o se desplazan con las ramas hacia los niveles más bajos. Los tipos de productos y sus niveles tecnológicos de elaboración se desplazan como ondas dentro del espacio geoeconómico a lo largo del tiempo.

Si un país periférico se ata o amarra productivamente a determinados productos estables en su madurez tecnológica, lo más probable es que se desplace negativamente hacia los países de menor desarrollo aún. Este desplazamienlo se relaciona con una esluctura dinámica de términos de intercambio que acompana a eslas ondas. Los países que se atan en su producción a un delerminado eje productivo o en una estética posición proporcional en su valor dentro del producto territorial, se moverán o desplazarán con esa onda, cada vez compitiendo en el mercado mundial con países de menor desarrollo relativo.

El desarrollo mundial y con éste el desarrollo inlernacional supone o asume un desarrollo sincrónicamente desigual de niveles lecnológicos y más aún la combinación de estos niveles. En este sentido los diferentes niveles lecnológicos entre naciones, son perfectamente funcionales a la reproducción a escala mundial. El atraso tecnológico de ciertos paises cumple una función en relación a los sectores más modernos tecnológicamente; no están al margen sino más bien son asumidos funcionalmente en un orden internacional.

f) La producción de las unidades productivas particulares y los porcenlajes de apertura o de orientación de la producción hacia el sector externo se incrementarán. Independiente de la localización de la planta, en un mayor porcentaje que el aclual, ésta se orientará hacia el mercado internacional. Las escalas y los lechos mínimos crecerán, olreciendo economias de escalas y elevando la competencia sobre una nueva plataforma.

Este hecho de la estructura productiva mundial hace inviable e irresponsable el proponer una estrategia con marcos nacionales como horizonte. Esto condena a las unidades productivas nacionales a desventajas en la competitividad provenientes de las deseconomias de escala, y a perder, tarde o temprano, e irremediablemente, el enfrentamiento económico. Esto excluye el caso de producción interna como estrategia particular para algún producto nuevo, pero no es aplicable como estrategia nacional.

g) El eslabonamiento de la producción a escala mundial tendrá consecuencias particulares para la negociación obrero/palronal, por la movilidad de las plantas productivas a nivel mundial. Los factores que condicionen la existencia, apertura o cierre de una planta dependerá menos 
de las condiciones locales y más del mercado o la estructura productiva en olros lados del mundo.

h) El tamano mínimo de los mercados ha crecido, la formación de bloques comerciales en el Tercer Mundo es ya más que una necesidad una realidad en proceso. Oponerse a eso es como enfrenlar con los brazos el movimiento de una aplanadora. Los movimienlos integracionistas está a la orden del día.

Las integraciones regionales y para nuestro caso la centroamericana se visualizan como una realidad y esta se concrelará no únicamenle mediante acuerdos simultáneos entre los paises que to componen, sino, más bien, implicará procesos paralelos y secuenciales de integraciones entre dos o más países como es el caso de los convenios entre Guatemala y EI Salvador firmados recientemente.

I) El problema en perspectiva ha dejado de ser la dependencia como se entendia en el periodo anterior, sino y hasta cierto punto lo contrario, es decir, cómo realizar una conexión conveniente con el aparato productivo mundial. Los grandes cambios mundiales implican cambios del "subdesarrollo" y no precisamente para una mejor situación. Más bien, para muchos países, eslará signilicando posiciones más marginales como proveedores de insumos o como consumidores. Es decir, su relevancia en el aparato y el comercio mundial se verá reducida aún más, como efectivamente está pasando en América Lalina

En esto es necesario enlatizar to contradiclorio de las lendencias mundiales actuales con respeclo al Tercer Mundo. Por un lado, hay un fuerte proceso inlegralivo que "mundializa" las economias domésticas de la periferia; pero, por otro lado, hay un proceso marginador de la importancia relativa interna y exlerna en la economia mundial. Es decir, si nuestras economias se ven en su proceso de reproduccción más integradas a la dinámica de conjunto, esto a la vez está implicando que en forma tendencial exportemos menos como porcentaje del PIB nacional en términos de valores mundiales y por otro lado sea menos significativa la participación en el comercio mundial ( Veáse Banco Mundial, 1991, p. 20).

La experiencia en los últimos años ha desvirtuado las tendencias de desconexión y desarrollo individual tal "Baratarias", o to que se conoce corno el modelo Birmano. Bajo diferentes significados, se pueden analizar las experiencias y siluaciones de Albania, Birmania, Cuba, Viel-nam, elc. En contraposición, lo que se identifica como la nueva tónica, no es oponerse a las tendencias económicas mundiales, ya que estas de diferentes formas e independientes de nuestras voluntades $y$ visiones, se 
realizan en el espacio total internacional. Las vias nacionales autárquicas implicaban básicamente enfrentar el espacio nacional en competencia con el espacio mundial. Esta lucha desbalanceada ningún pais está en capacidad de ganarla.

Lo que está ganando consenso en el mundo es la conformación de estrategias nacionales que partan de las tendencias económicas mundiales como algo objetivo y dado, y sobre ellas colocar a los países en una posición para canalizar dichas tendencias en función de los intereses particulares a cada uno $y$ de los sistemas sociales y modelos politicos que se quieran impulsar. Eslo significa tener la mayor conciencia y conocimienlo sobre las tendencias mismas a escala mundial y aprovechar las caraclerísticas particulares geográlicas, políticas, económicas y tecnológicas en función de reinsertar el pais con nuevos productos y nuevas tecnologías.

La economia mundial se está volviendo a escala global más interdependiente, y en ella los paises del Tercer Mundo eslán disminuyendo su importancia relativa de forma negativa en cuanto a exportaciones e importaciones. Anle esle hecho, no se puede seguir una eslralegia nacional atomizada o darle la espalda a esla siluación de la gran lendencia mundial para supuestamente seguir un camino nacional aislado. Esto sencillamente significa no entender los procesos actuales a escala mundial.

El desarrollo centroamericano no se puede plantear como un problema intemo o de desarrollo hacia adentro, más bien el problema actual es el identificar espacios y sectores convenientes de integración Centroamericana y de apertura colectiva hacia el mundo. En este espacio es donde se tienen que buscar las formas de consensuar y persuadir a las principales fuerzas sociales y económicas. Dada la actual siluación de las lendencias mundiales, la posición menos envidiable es la de aquellos países que no logran superar sus problemas internos o de unilicar las fuerzas sociales en función de estrategias nacionales.

k) Es necesario insistir sobre la actual ineslabilidad del mercado mundial capitalista. Eslo es importante identilicarlo para no creer que el nuevo orden está ya inslaurado. Más bien, la economía mundial se debate aún en la encrucijada económica de la transición. Por su importancia, vale la pena hacer la siguiente cita (ICl y CEPAL, 1989, pp. 30-31):

Hasta ahora, Eslados Unidos ha sido, con mucho, el principal mercado para la exporlación de manulacturas, especialmente de las provenientes de los países en desarrollo. Entre 1981 y 1984 se duplicaron las importaciones de bienes manulacturados de los países en desarrollo por parle de Estados Unidos, pasando de los 34 a los 70 mil millones de dólares; mientras tanto, las importaciones 
desde Japón sólo aumentaron en dos mil millones de dólares, en tanto que las importaciones procedenles de Europa se redujeron. En 1985, el 62 por ciento de las exportaciones de manulacturas provenientes de los paises en desarrollo hacia los palses de la OCDE tuvieron como destino los Estados Unidos. Durante los primeros cinco años de la década de los ochenla, mientras la demanda en los otros palses desarrollados descendio y luego se estancó, Estados Unidos se convirtió en el comprador de última instancia y aportó el mayor impulso para el crecimiento de los palses en desarrolio, es decir, especialmente para las ERls de primera línea en los palses asiáticos.

En el futuro, la importancia de la economla de Estados Unidos, en relación con las exportaciones de productos manulacturados inevitablemente tenderá a disminuir. Ello refleja, simplemente, tres factores fundamentales de desequilibrio estructural que se han acumulado en la economia estadounidense desde fines de los años setenta: una deuda récord, cuyo monto superó los 400 mil millones de dólares hacia lines de 1987; un creciente déticit comercial que excedio de los 140 mil millones de dólares a fines de 1987; y un elevado délicit que alcanzó más de 150 mil millones de dólares al finalizar el año fiscal de 1987. Como resultado de tales desequilibrios se producirán, inevitablemente, cambios notables en la integración de la economía de Estados Unidos en los mercados mundiales. En vista de las limitaciones para ampliar las exportaciones de los Estados Unidos tanto de bienes manulacturados como de servicios, la mayor proporción de dicho ajuste deber producirse por medio de una reducción considerable de las importaciones de dicho país, sea a través de la recesión o por medio de una sustitución selectiva de las importaciones dentro de una política industrial deliberada. Dicho de otro modo, la fuerte concentración de las exporlaciones industriales a nivel mundial en la economla de Estados Unidos constituye un anacronismo que no puede mantenerse por mucho tiempo más. Aclualmente, Eslados Unidos absorbe cerca del 70 por ciento de las exportaciones de manufacturas provenientes de los países en desarrollo, mientras que Japón, absorbe solamente el 8 por ciento. Puesto que la economía japonesa equivale a casi dos tercios o tres cuartos de la economía norleamericana, dicha situación evidentemente tendrá que cambiar....

...Los Estados Unidos debe aumentar sus exportaciones o disminuir sus imporlaciones no por un valor de diez, veinte o aún cincuenta mil millones, sino por un monto de cientos de miles de millones de dólares. Dentro del contexto del estancamiento de la demanda mundial y de los mercados crecientemente más cerrados, simplemente no existe suticiente demanda para tal ampliación masiva de las exportaciones de los Estados Unidos.

Esta siluación se puede sinletizar en tres aspectos,

- Por un lado, Eslados Unidos eslá en su límite de importación y con grandes déficits en su balanza comercial.

- Adicionalmente, los paises del Tercer Mundo eslá agobiados con su deuda externa, lo que les imposibilita participar o demandar mayor cantidad de productos del mercado internacional. Los países del Este no constituyen, por hoy, ninguna demanda efectiva de relevancia. 
- Además, se enfrenta el eslancamiento de la Ronda del Unuguay en el GATT (y el proleccionismo de los paises centrales hacia productos periléricos) para crear una nueva estructura más amplia del mercado mundial, que permila viabilizar y sacar al comercio inlernacional de su aclual estancamiento.

Ahora bien, es necesario enfalizar que, aunque existan eslos grandes desequilibrios que pueden profundizarse más con la posibilidad de una gran crisis económica mundial, la crisis y los desequilibrios económicos mundiales generarán, tarde o temprano, un nuevo orden económico mundial. Dentro de este nuevo orden económico mundial, encontrar una mejor ubicación aquellas naciones que hayan conlormado procesos de reinserción lo más temprano posible y de la forma más conveniente; es decir, aquellas que hayan tenido una perspectiva histórica más clara del nuevo orden económico mundial.

L) En el caso particular El Salvador, la concreción de este nuevo orden económico mundial puede ser abordado o realizado de dos maneras:

Una de ellas es ajustandose a esle nuevo orden mundial, o transformándose productivamente sobre la base de ese nuevo orden mundial. El "ajustamiento" a este orden económico mundial significa el cambio de la estructura productiva en función de la reasignación funcional proveniente del mercado mundial. Significa, asi, una adecuación pasiva: simplemente dejar abiertos los canales a la realización de las tendencias mundiales al interior del país.

El otro camino es la reestructuración productiva. Esto significa la acción consciente en política económica para buscar consistentemente una nueva ubicación en la estructura producliva mundial, más convenienle de la que lendencialmente pueda asignar el mercado. Esta función productiva, además, está por encima de las formas en las que se distribuye el producto a nivel nacional o de la participación en la dirección de la producción de las clases trabajadoras.

Precisamente es en esto que radica la diferencia entre ajusle estructural y reestructuración productiva: la segunda reconoce e identilica los necesarios equilibrios dinámicos macroeconómicos y los cambios esıructurales en la oferta y la demanda. A estos cambios se les ofrece un contenido concreto de realización que garantice el mejor papel de un país en la estructura productiva mundial. En cambio, el ajuste esiructural, en última instancia no hace más que viabilizar, de una lorma pasiva, las grandes tendencias mundiales en lo que respecta a las posibilidades productivas del pais. 
Al ubicar la necesidad histórica del ajusle estructural, y en especial las medidas orientadas a reestructurar la olerla nacional, se puede identilicar que éste canaliza y viabiliza las nuevas tendencias productivas a escala mundial respecto al pais. Al eslablecer mecanismos que buscan la eficiencia, la rentabilidad y la compelitividad, el ajusle viabiliza pasivamente las ramas que son renlables en ese momento para el pais. Visto de otra manera, la rentabilidad inmediata a cada pais es la que manifiesta y permite el desarrollo de las ondas productivas mundiales en el espacio nacional. De esta manera, las reinserta a nuevas ramas y al aparalo productivo mundial.

El ajusle es una lorma de reinserción al nuevo orden económico mundial, pero es una forma de reinserción en la cual el pais se adecua a las tendencias del mercado mundial. El ajusle libera y promueve estas tendencias mundiales, pero no las orienta en función de los objetivos estratégicos nacionales de desarrollo. Así, el ajuste no es una estrategia nacional del desarrollo. Es a lo sumo, lal como su nombre lo expresa en su sentido literal, un plan no para ajustarse al nuevo orden económico mundial, sino para que ésle, el mercado mundial, ajuste nuestra economia a su dinámica.

En sus objetivos formales, pretende establecer un nuevo equilibrio entre la oferta y la demanda, establecer un nuevo balance en el intercambio de flujos entre el país y el sector externo, en el sentido de reesinucturar la demanda o de reesinucturar la oferta promoviendo nuevas proporciones en la planla productiva en cuanto bienes transables sobre los no transables y nuevas relaciones más reales de precio entre los productos. Con todo ésto, el ajuste expresa ias demandas de reinserción en la nueva estruclura económica mundial.

La readecuación histórica de la economia es ineludible para cualquier gobierno. El problema estriba en la participación de los agentes económicos en los coslos del ajuste y el conlenido malerial que le dará el carácter histórico al ajuste estruclural. Este contenido histórico sólo lo puede dar una estralegia nacional de desarrollo que visualice los grandes objetivos e intereses nacionales, que idenlifique las ramas concretas y las formas de producción en la nueva esiructura productiva, por encima de los inlereses inmediatos. El ajuste estructural no otrece eso.

En esta línea, la reestructuración producliva niega y supera el conceplo de ajuste estruclural en cuanlo que identifica su necesidad y su límite y le da el contenido malerial necesario en función a la estructura técnica en el orden mundial. El ajuste expresa de alguna manera una necesidad histórica, pero tiene el límite de omitir el contenido productivo $y$ las relaciones entre los agentes económicos. 
En el caso particular de El Salvador, se presentan problemas de reducción y conlusión y, más que eso, de superficialidad en el análisis. Esla superficialidad tiene serias consecuencias ante las demandas históricas que se tienen en aras de la reconciliación y reconstrucción nacional $y$ en función de reinserlarnos en la economia mundial. Por la misma guerra, se enirentan retrasos de respuesta con respecio al avance que tienen otros paises en la comprensión de los desafíos mundiales y en la conlormación de respuestas y estralegias nacionales. En estos casos, se tienen dos ejemplos concrelos y próximos de un buen nivel de formulación como es el de México y Cosla Rica.

\section{Una Estrategla naclonal de desarrollo: dlez elementos como base para una reestrucluraclón productlva}

Toda época tiene sus antinomias y sus contradicciones que se niegan entre si y que se postulan como la única verdad. Cada una anatemiza a la otra y se desarrollan como negación respectivamente. Más la verdad de cada época y en cada época se encuentra en la unidad de todas las parles, de todos los pensamientos y de las diferentes escuelas.

El periodo que está linalizando en América Latina y en El Salvador, también se caracterizó, en cuanlo al pensamiento económico y las estrategias de desarrollo, por eslos dualismos:

Desarrollo hacia deniro vrs desarrollo hacia fuera,

Modelo dependiente vrs independiente.

Industrialización vrs agroexporlación,

Enajenación vrs liberación,

Modelo tradicional vrs modelo alternativo,

Modelo económico vrs proceso económico,

Estatismo vrs liberalismo. etc

Ahora que se identifican estos dualismos y unilateralidades de la época pasada en cuanto a la leoría del desarrollo, ciertos autores y personajes políticos quieren demostrar que su pensamiento de antańo no contenía tales unilateralidades. Siempre hay una trase dejada como recurso de "integralidad" ante la posible crítica lutura de la historia. Son esas frases que lodos los que han escrito sobre temas polémicos alguna vez dejan en la saga del discurso, por cobardía o por miedo a equivocarse. Son puntas suellas de las cuales asirse anle la posibilidad de que los vientos teóricos cambien. O, lambién, son frases pasadas que forzosamente se reinterpretan anle los nuevos marcos intelectuales que son producto de la necesaria evolución del pensamiento. 
Hoy asistimos en América Latina a la superación de esos viejos dualismos en la expresión de unos de sus viejos polos:

Cabe advertir que el examen del tipo de industrialización que tenemos en menle no se inscribe en el debale de estralegias aperturislas frente a estralegias orientadas hacia el mercado inlerno, sino en el imperativo de elevar la productividad y de ganar eficiencia en nuestros sislemas productivos, indistintamente de si se trala de exportar o sustituir imporlaciones. Ese es el sentido cabal del conceplo de la "competitividad internacional (Fajnzylber, 1989, p. 12)

Se enfrenta una época en la cual se reconoce la necesidad de los instrumentos macroeconómicos de política para el desarrollo, pero a la vez se exige la necesidad de políticas microeconómicas orientados a la producción. Se reconoce la necesidad de los equilibrios macroeconómicos y simultáneamente del cuidado de su impaclo social; de la reasunción y ubicación del papel del mercado, pero así también del cambio y de un nuevo papel del Estado, elc.

Existe una dinámica de reubicación conceptual y de política económica más allá de lo que cada escuela y sector pueda percibir. Hoy, en cuanto a estrategias de desarrollo, en principio no se parte de lo deseable sino más bien de lo posible en un conlexto táctico que está más allá de nuestros deseos y voluntades. El volunlarismo está dando lugar al realismo. Hay, sin embargo, vacios en las propueslas de la agenda económica que es necesario superar y en eslo todos los sectores tienen que aportar y contribuir.

Se pueden identilicar 10 elementos de eștrategia general, que, como ejes estratégicos, integran y superan las anleriores dualidades. Eslos diez punlos constituyen, a la vez, la agenda económica de la discusión nacional; son los temas de los cuales se tiene que partir para la formulación de una estrategia de desarrollo para El Salvador.

La identificación de los puntos se basa sobre lo que es posible, pertinente y relevanle en esle momento histórico.

\subsection{La economia mundial como marco prlmario y centroamérlca como el marco específico minimo de aplicación económica}

Para el planteamiento de cualquier fundamento de una estrategia de desarrollo en cuanlo a la esiruclura de pensamiento $y$ realidad, debe establecerse el marco del cual se parte, es decir ,de la cosmovisión del todo económico; de la relación entre todo y parte, de la comprensión de la nación y su relación con y dentro del mercado mundial.

La concepción del mundo como tolalidad es el principio y punto de 
partida para la conformación de una esirategia nacional de desarrollo en cuanto categoria. Esto se contrapone a la comprensión del marco nacional como punto de partida. Hay, en este sentido, un fundamento que separa la estruclura de la exposición que aquí subyace a las estrategias que parten del marco nacional.

Esle segundo enloque, es decir el marco nacional como punto de partida, expresa la concepción de las teorias de desarrollo del periodo pasado, en el cual el mundo se concebia como unidad atomística. La economia mundial era la unidad de las economias nacionales y en el que la estruclura de las relaciones mundiales no traspasaba la estruclura de las relaciones internacionales. La dimensión más profunda de lo real que subyacía a la economía nacional en esta concepción se reducía a un nivel intermedio de su realidad y explicación. Esta concepción correspondía a un nivel de la comprensión y avance en el desarrollo de las ciencias económicas y en las teorias del desarrollo y en cierto sentido, 0 quizás en el fondo lambién, al nivel alcanzado en la integración de la economía mundial.

Las naciones eran individualidades en las cuales cada una tenia su propio camino o había una relación de condicionalidad externa como dependencia o dominación. Existian relaciones entre ellas pudiendo establecerse en un mundo sin unidad, jerarquias de naciones como realidades económicas alomizadas. Era una concepción del lodo y las partes como unidad o como conjunto de individualidades, en la cual existía una estructura de relaciones entre naciones que se explicaba por si misma y por la conformación alcanzada al interior de cada nación

La teoria de la dependencia, las teorias del desarrollo nacional y las estrategias que poslulaban modelos independientes a ultranza no lograban traspasar, más allá de cualquier ideologia, este limile en la comprensión de los ienómenos mundiales.

Ahora se concibe la economía mundial como unidad productiva que se diferencia en niveles de concreción y en niveles de comprensión y desarrollo al inlerior de las naciones. Las naciones, en esta perspectiva, no son unidades como tales, en abstracto, sino en cuanto expresan y conjugan como parte diferentes elemenlos y componentes de la economía mundial. Una nación no está integrada cual pieza mecánica en el engranaje económico mundial sino que es, en lanto nación, parte de esa economia mundial.

En este sentido, el desarrollo económico y la teoria del desarrollo económico, en primera instancia, no es una teoria de sociedades, paises o naciones. Es la teoria del desarrollo económico mundial como un todo, 
como unidad en la cual los procesos especílicos de cada nación no son etapas secuenciales por las cuales pasan todas las naciones sino más bien, la maduración de los elementos dentro de un todo. Es decir, son procesos particulares propios de esa parte dentro de esa economia mundial, en un tiempo, en un periodo histórico y en la particular conformación de ese bloque económico mundial.

Nunca va a existir un nuevo proceso como el de Inglatera, EUA o Japón u otros países como la Unión Soviética. Cada uno de estos procesos corresponde, en primera instancia, a diferentes momentos del desarrollo de la economia mundial y corresponde a necesidades particulares de desarrollar ciertas partes dentro de la unidad funcional y contradictoria de esta economia total. El desarrollo de una de las partes deviene en primera instancia, de la unidad y necesidad económica mundial y en un segundo momento, de la especificidad de la parte, que logra que suceda de esa manera y haya sido ese pais y no otro que se realice tal necesidad.

Esto tiene consecuencia para la conlormación de un modelo y estrategia de desarrollo. Implica que más allá de los deseos y voluntades, las posibilidades de desarrollo o de la concreción de un modelo particular para el pais no eslá dadas por un marco nacional como lo puede plantear enfáticamente alguna fuerza política en particular, pretendiendo que con esto se reafirma una cuestión de principios y se diferencia de su contendiente.

Aún ante la posibilidad de aislamienlo temporal, ninguna nación puede escapar al proceso integrativo mundial que sobrepasa la dimensión del tiempo y espacio de las naciones en particular. Esto por la sencilla razón de que el espacio de desenvolvimiento de las fuerzas productivas $y$ tendencias de homogenización de los procesos productivos es precisamente el espacio de la economia mundial y no el espacio de las economias nacionales.

Eslo implica que para formular los principios y elementos de un modelo de desarrollo nacional no se puede partir en primera instancia de las necesidades especificas de los países, sino del marco dentro del que se desenvuelve la economia mundial, con sus ramas niveles lecnológicos, tendencias de consumo, etc. Dentro de éste marco y tendencias, que eslá más allá de las posibilidades de transtormación unilateral de las fuerzas salvadorefias en lo inmediato, es que se puede lormular y desenvolver una estrategia de desarrollo nacional. Planlearlo de otra manera es negar o desconocer el avance de la teoría del desarrollo y sobre todo de la realidad misma; y estar preso de marcos obsoletos y arcaicos de las teorias del desarrollo que caracterizaron el periodo de la posguerra. 
Por otra parte, la conformación de este marco estralégico nacional o modelo de desarrollo no es posible concebirlo en absiraclo, al margen de la economía o ignorando que exisle un espacio de desarrollo específico en el cual se desenvuelve la actividad productiva. Así como existe un marco general dentro del cual se desarrolla el análisis y planteamiento de una estrategia, existe un marco mínimo específico a considerar que constituye la plataforma inmediata o base especítica sobre la cual se erige la actividad productiva de cara a la economia mundial.

A diferencia de lo que plantean aquellos sectores que pretenden estructurar la producción de cara al mercado mundial exclusivamente, la estrategia tampoco se conlorma abslrayéndose de las necesidades o de la estruclura productiva nacional particular. Es necesario concebir e interpretar la forma como el engranaje y la demanda de la estructura producliva nacional se vincula y estruclura con la internacional.

Eslo lleva a la necesidad de dislanciarse de dos renovadas y viejas unilateralidades. Por un lado, el globalismo, que niega la realidad económica del Estado nación, no lo articula dentro del nuevo orden internacional y lo reduce a mera plataforma de exportación en el espacio geográfico. Por olro lado, el alomismo nacional mundial, que no logra ubicar el Estado-nación dentro de la unidad producliva mundial y asume la producción mundial como la suma de las producciones nacionales, disfrazándose como un nacionalismo populista ya sea de derecha o de izquierda.

La negación de ambas posturas (el globalismo y el atomismo) es decir su superación, implica reconocer por un lado la crisis actual del viejo orden y a la vez, que, tarde o temprano, se impondrá un nuevo orden económico mundial más allá de las inestabilidades o la prolongación de éstas.

El nuevo orden mundial implicará, por un lado, niveles más altos de integración económica a nivel mundial de los que hasta ahora se han presenciado. Seguramente, esto llevará procesos contrarios, es decir, procesos de marginación o exclusión mundial, expresados por la profundización de las diferencias relativas o brechas inlernacionales. Sin embargo, como cualquier sistema, ésle será viable en la medida que asegure su propia reproducción, es decir, según lo que se ha expuesto anteriormente sobre los equilibrios y cambios mundiales, que este orden de una u olra forma debe eslablecer ciertos equilibrios y proporcionalidades, nuevos rangos de oscilación y márgenes que aseguren la reproducción de las fuerzas productivas, incluida la fuerza de trabajo. Cuando éslo no sea asegurado, se estará en presencia del final de una era que va más allá de una mera crisis secular o periodo histórico. 
A este nuevo orden mundial corresponderá una nueva estruclura internacional. La realidad del Eslado/nación no desaparece sino que se Iranligura acorde a la nueva necesidad hislórica mundial. En esle sentido, seguirá existiendo el Estado-nación, redefinido en sus posibilidades de injerencia o en sus áreas de acción. Esto implica nuevas dimensiones de los espacios de posibilidades de la politica económica. Sobre esta base de procesos integrativos y exclusivos, y de una nueva naluraleza del Eslado nación, es que se deben plantear nuevas formas de eslralegia a nivel nacional y regional. Es decir, el marco espacial de la injerencia estatal en cuanlo a política economica es redefinido.

No es que desaparezca la posibilidad de la política económica, como lo puede plantear una visión globalisla a ultranza, ni lampoco que se mantenga el viejo conceplo de estrategia nacional de desarrollo, sino más bien que se crea un nuevo mundo en el que se redeline el mismo concepto de estralegia de desarrollo, y la polílica económica. Sin embargo, el marco mínimo de aplicación ya no puede ser, para nuestro caso. El Salvador: no puede ser una estralegia del pais lal como se ha entendido hasta ahora. Este marco minimo tiene necesariamente que ser y elevarse al espacio de Centroamérica, primero como necesidad del desarrollo económico en particular, y segundo por las mismas lendencias integrativas y de formación de bloques a nivel mundial.

Es un error partir de que la estrategia de desarrollo debe tener como marco inicial lo nacional, lo regional y por último lo inlernacional. Es precisamente a la inversa como debe plantearse el fundamento melodológico. Se debe tener como marco básico la eslructura productiva mundial, y como marco especíico mínimo de desenvolvimiento de la actividad económica el MCCA. Es la lotalidad el punlo de partida.

Esle marco mínimo es una necesidad de sobrevivencia en la competitividad, entendiendo que las escalas del mercado condicionan las escalas de producción y las economias de escala. Las escalas de producción de El Salvador, orientadas únicamente al mercado nacional, condicionan los niveles tecnológicos y los niveles de competitividad a los que se ven enfrentados los productores nacionales. En la medida que el mercado al que la eslrategia se dirija sea más amplio, se posibilita elevar las escalas de producción y de exigencia en calidad. A la vez, con una apertura y amplitud del mercado, se eleva la competitividad de las empresas centroamericanas con respeclo a la producción mundial.

En esle proceso integrativo con respeclo a centroamérica y el mundo entero, está involucradas todas las naciones en una carrera contra el liempo, en función de buscar posiciones ventajosas dentro de la estructura mundial; $y$ en este marco mundial debe insistirse que el tiempo 
cuenta. Los espacios de mercado o de producción que son abandonados por un pais o por una unidad productiva, o aquellos que no son cubiertos por circunslancias coyunturales que retrasan el proceso de respuesta ante la demanda, son inmedialamente tomados por otro oferente. La recuperación o reconstrucción de eslos espacios perdidos en el mercado mundial, serán diticilmente reconquistados o reemplazados, tendrán coslos en el tiempo y en las ubicaciones funcionales. La reasignación de la cuota de calé para El Salvador o del petróleo para ciertos países árabes son ejemplo de esto.

El pais no tiene todo el tiempo del mundo para resolver sus problemas y ganar la posibilidad de una reinserción conveniente, como si los demás países estuviesen esperando por El Salvador y para devolverle traternalmente sus espacios, como si éstos fueran realidades estáticas. Más bien, enfrentamos estructuras de oportunidades dinámicas que se vuelven menos convenientes o tavorables en una relación inversa con el tiempo. Las polencialidades del pais de cara a la economía internacional no existen en sí mismas, sino en el marco de la necesidad del proceso histórico y económico mundial. No es lo mismo resolver los problemas y enirentar los desafíos ahora que dentro de cinco años.

En este caso, debe considerarse, por ejemplo, la ubicación en la que se encuentran países con planteamientos inicialmente de desconexión y rellexionar sobre su viabilidad y supervivencia económica denlro de la economía mundial y al interior de los procesos inlegracionistas. El marco de la compelencia tecnológica y de extensión mínima de los mercados exigen actiludes realistas ante este nuevo orden económico mundial. Esto implica una nueva actilud hacia el mercado mundial, en el sentido de que el proceso integracionista lleva a la coniormación de un sólo precio a nivel mundial y tarde o temprano esla ley termina imponiéndose en los mercados particulares, ya sea entrando por la puenta, por la ventana o derrumbando la pared.

En este sentido, cualquier elemento dentro de la estrategia nacional que tenga un fin proteccionista sólo puede ser explicable o aceptable dentro de marcos limitados en el tiempo y orientados a favorecer el surgimiento de alguna industria de carácter estratégico, pero nunca como forma de desarrollo indefinida en el tiempo. Cualquier ley proleccionisla o marco regulalorio no debe ir orientada o tener como consecuencia la prolección de la ineficiencia tecnológica; a lo sumo debe limitarse temporalmente a proteger los coslos de desarollo inicial de cualquier empresa por periodos especílicos, y esto es aplicable a cualquier sistema económico que se tenga en menle. 


\subsection{La reestructuración Integral de la planta productiva como politt- ca Industrlal.}

Para el planleamienlo sobre la necesidad de una reesinucturación productiva se tienen antecedentes acluales de carácter mundial y de naturaleza histórica .

Los antecedentes de carácler mundial se refieren al cambio y la resinucturación producliva, que implica y genera cambios tecnológicos de proporciones y jerarquías inter-ramas analizados en los primeros capítulos. Esle hecho obliga a cualquier pais a translormar la estruclura productiva si pretende mantener posiciones relativas o a mejorarlas en el mercado internacional. En caso de no tener capacidad y desarrollarse Iransiormaciones deslasadas, el pais liende necesariamente a ser desplazado a posiciones más periféricas en el engranaje productivo mundial.

Para prever y reaccionar oportunamenle, debe entenderse que el desarrollo tecnológico no es un proceso que se da en o que tiene como marco el espacio de naciones, sino que se da en el espacio mundial, afectando las estrucluras productivas de todas las naciones y más aún de la estruclura internaciones. De esta manera, la exigencia de los cambios en la eslructura productiva debe entenderse como consecuencia del desarrollo tecnológico resultante de la compelencia en los mercados mundiales por el control o ampliación de espacios delerminados.

Los antecedentes de naturaleza histórica se refieren a la estralegia de industrialización en Latinoamérica del periodo de la posguerra, las cuales se orientaban a la industrialización como estralegia nacional de desarrollo, que aparentemente se contraponia y aislaba del mercado mundial pero que en el fondo realizaba y expresaba la tendencia mundial de industrializar las ramas de medios de consumo en el Tercer Mundo.

Dicho modelo libraba aparentemente dos pugnas y contradicciones: se postulaba por un lado como negación al mercado mundial y en ese sentido como estrategia independiente de desarrollo. Por otro lado, en contraposición al modelo de agroexportación, al sector agroextractivo exportador de cada país y a su retraso tecnológico especílico, se presentaba como sector moderno tanto a nivel tecnológico como en las relaciones sociales anle el alraso del sector primario.

Esta visión en América Latina ha sido fuertemente cuestionada y superada no sólo por sus detractores, sino también por sus principales defensores (la CEPAL).

En la definición de nuevas estrategias de desarrollo lambién se ha replanteado el concepto de induslrialización y de política industrial. En esle sentido, se cuestiona actualmente la visión parcial y su restricción a 
ser concebida como una estrategia de desarrollo orientada al sector secundario, se llega asi a cuestionar que el desarrollo se fundamente únicamente en el desarrollo del seclor secundario. Cuando se hablaba en ese entonces de política industrial, su concepto era entendido y utilizado en su acepción restringida, como política sectorial, comprendiéndose como acciones orientadas al sector secundario de la economia: el induslrial. Esta acepción del lérmino liene como base la forma general y tradicional de clasificación de la actividad económica en tres sectores: agropecuario (primario), industrial (secundario) y servicios (terciario). Así, se hablaba de política económica seclorial, agropecuaria, industrial, etc.

Ha habido una ampliación de la concepción de estrategia productiva y de la concepción de política industrial. Actualmente, se enliende la política industrial como política de producción orientada a la articulación de bienes y servicios de todas la ramas de la economía en función de objetivos globales de desarrollo. Se cuesliona, adicionalmente, la concepción de reconversión industrial últimamente en boga, al limitar este concepto en la práctica a la modernización de la planta productiva, y específicamente solamente de una rama en la clasificación del CIIU. 0 , en su versión más amplia, este conceplo pretende afectar únicamente el sector secundario y no la forma de inserción real en la producción mundial por medio de niveles tecnológicos y tipos de productos.

A la restricción de la política indusirial en el objeto, suele ocurrir to mismo en cuanto a los objetivos de ésla, asi como de sus instrumentos y componentes: se identifica política industrial con Industrialización, con Reconversión Industrial o con programas de Invesligación y Desarrollo (I\&D), elc. También la formulación o existencia explícita de políticas industriales se identifica con determinados tipos y formas de Estado y de planificación y hasta con escuelas y sistemas económicos.

En oposición a estas formas reductoras, es necesario, en principio, delimitar y definir el objeto de la política induslrial. Esta es la esfera de la producción principalmente en cuanto a su contenido técnico material y no únicamenle restringida a su forma social (es decir, la forma específica que adquieren las relaciones entre los hombres en el proceso de producción). Estos elemenlos en un principio, indican que la política industrial escapa en su comprensión y formulación únicamente a las Ciencias Económicas. El ámbito u objeto sobre el cual recae la política industrial es la estera de lo real en lo económico, la producción material, la estructura técnico-malerial del capilal productivo en todas sus ramas. De esto se deriva su objetivo general que es la búsqueda de la asignación, articulación lécnica y configuración óptima de los recursos nacionales en lunción de maximizar de lorma estralégica el producto real nacional. Es 
decir la búsqueda del patrón o estructura productiva, de la estructura técnica del palrimonio nacional y de la matriz de flujos interindustriales que maximice sostenidamenle el ingreso.

La existencia de una política industrial no depende de su grado de explicités, es decir, de si el Estado o las clases dirigentes expresan nominalmenle su existencia en cuanto polílica en un plan de gobierno, sino más bien de las perspectivas y de las acciones reales.

Actualmente, con diferentes grados de enlendimiento, se planlea "la impostergable transformación productiva de América Latina". En el caso de El Salvador, deberia entenderse por transtormación productiva el cambio de los niveles tecnológicos, la reconformación de la planta productiva a través de un nuevo peso y equilibrio entre las ramas del patrimonio nacional y el cambio en la estructura del producto. La expresión también haria referencia a las formas de participación, administración y conciencia de los agentes productivos.

Es decir, la transformación productiva como nueva política industrial que requiere El Salvador afectaria el contenido técnico, la estructura del contenido y de valor, las proporciones de sus partes y componentes, las relaciones insumo-producto, la inserción y la relaciones con la producción mundial, así como la calidad y participación de los agenles empresariales y laborales. Específicamente, la rearticulación de la economia nacional y centromericana en el espacio mundial se viabiliza a través de dos vectores fundamentalmente: la translormación tecnológica y la transformación de los tipos de producto.

Pero esta transformación productiva no tiene sentido en si misma, sino en funcion de los grandes objelivos nacionales: la elevación de la competitividad nacional y la salistacción de las necesidades de la reproducción social. Lo que se busca es una plalaforma competitiva de en el nuevo mercado mundial, lomando en cuenla la producción mundial en cuanto que la competitividad no es un problema de desarrollo hacia adentro o hacia afuera, sino que es un problema de sobrevivencia y desarrollo de la esıructura productiva nacional (Véase Fajnzylber, 1989).

Denlro de este marco de objetivos generales, se pueden plantear objetivos particulares derivados de los anteriores como son el diversificar la estruclura económica vinculada a la economía mundial en cuanto importaciones y exporlaciones; elevar el nivel de consumo y de vida de la población así como su calidad, incrementar el valor agregado de los productos de agroexportación, etc. Sin embargo, estos objetivos más particulares o más especificos derivan de los dos primeros y su alcance, concreción y viabilidad dependerá de ellos (Véase Fajnzylber, 1989). 
Al pretender conformar la transformación productiva como nueva política industrial, se reconfiguran viejos conceptos y áreas de acción y otros se simplifican. En las Ciencias Económicas, en lo que compele a política industrial, se puede observar poca atención y desarrollo de sus elemenlos conceptuales y lécnicos, especialmente en los ámbilos universitarios o académicos de influencia Keynesiana. Las razones probablemente se encuentren en la naturaleza del pensamiento keynesiano y de los insir: mentos y medidas propueslas de carácter global y macroeconómico, asi como en su orienlación a influir en la demanda agregada más que en la oferta. Una política industrial por delinición afecla la producción, la oferta, ámbito no preferencial de nuestras universidades. Es en el pensamiento neoclásico, a través de la teorias de los precios sociales y del instrumental de formulación y evaluación social de proyectos, de la teoría microeconómico sobre el ciclo del produclo y la relación óplima de factores (Isocuantas), la curva de transformación, la matriz insumo producto, el ciclo induslrial, etc, que se encuentra una mayor preocupación e instrumental sobre la forma de incidir en la oferta y en su estruclura.

Pero realmente el éxito de una pólitica industrial no está en su amplitud, en su grado de complejidad o en el desarrollo técnico en su formulación. Más bien, estaria en su simplicidad, realismo y concreción, concentrando esfuerzos en lo fundamental, asi como en la conciencia y consenso social de las fuerzas reales de las cuales dependería su implementación.

Cinco áreas son cardinales en la conlormación de una nueva política industrial para El Salvador:

- La identificación de los complejos especializados/integrados de desarrollo y reinserción en el mercado mundial en contraposición al conceplo de polo de desarrollo.

- El desarrollo de una planta productiva con flexibilidad de adaptación al mercado y vinculada al esludio permanente de los cambios del mercado internacional como mélodo.

- La conformación de instancias desburocratizadas y descentralizadas nacionales de coordinación estratégica entre estado, universidades y sector privado.

- La ubicación de la importancia de los planteamientos económicos microlocales.

- El desarrollo del aparalo malerial de comunicación y transporte. 


\subsubsection{La identlficación de complejos especiallzados e Integrados de desarrollo y de relnserción en el mercado mundial en contra- posiclón al concepto de polo de desarrollo.}

Los complejos de desarrollo se orienlan a conformar nudos de engranes de ramas y nudos especíicos de producción que por su allo valor vinculante con otras ramas, tienen una alta capacidad dinamizadora y de competitividad nacional e internacional. Estos complejos requieren identificar los ejes a través de los cuales el país se inserta en el mercado mundial y se vuelve competitivo respecto al mercado de consumo nacional . Esta identificación es indispensable ya que debe tenerse la convicción de que la reinserción y la competencia en el mercado mundial no es posible en todas las ramas

El concepto de complejo especílico de desarrollo implica en cierto senlido, la superación del conceplo de polo de desarrollo que tiene una dimensión más espacial en el ámbito nacional. Este concepto parte de la existencia de un mercado nacional protegido considerando que el desarrollo de pequeñas industrias dentro de estos polos podrian complementar la integralidad producliva en ese espacio determinado. El concepto de polo de desarrollo tiene como fundamento el construir una integralidad productiva nacional por medio de especializaciones y diversificaciones internas. En el londo, persigue y cree posible la unidad productiva de la planta producliva nacional en una relación de intercambio de excedentes con el exterior.

Actualmente estos armónicos y viejos conceptos de desarrollo se pretenden superar tomando en cuenta la realidad mundial y los procesos de integración productiva y de consumo. El concepto de complejo hace más relerencia a la integración de ramas económicas, a la identificación de ramas especílicas en relación con ramas complementarias y auxiliares orientadas al mercado mundial y a la competencia interna. Alrededor de estas ramas se realiza un engranaje de unidades productivas más especializadas y de diferente tamaño, propiciandose una relación matricial a escala inlerna muy productiva. A partir de estos complejos, se vinculan y unen unidades empresariales inlegradoras de produclos y unidades especializadas de fabricación de componentes de productos (Véase el ejemplo del caso chileno en Pensamiento Iberoamericano Pág. 69).

El eje de la nueva eslralegia no son los polos, sino los complejos integrados. Ahora bien, estos úllimos no niegan a uliranza el conceplo de polo y en un senlido concreto to puede contener. Esto es posible al darle una dimensión espacial al complejo integrado de ramas.

Si no se acepta la necesidad y la responsabilidad de plantear estrate- 
gias nacionales de desarrollo, cualquier fuerza política puede reducir su planteamienlo a la estrategia de polo al preocuparse económicamente de las áreas geográficas que considera de su influencia. Esta reducción seria un error histórico imperdonable desde cualquier punto de vista.

\subsubsection{Una planta productlva con flexlbilldad de adaptación y vincu- lada permanentemente al esludio del mercado Internaclonal como método.}

Esle concepto hace referencia a la capacidad de respuesla flexible de la planta productiva nacional, a su capacidad de adaplación al cambiante mercado. Los ciclos productivos y los de vida del producto se ven fuertemente reducidos en este nuevo periodo y las ondas de lipos de producto se mueven en el espacio geográfico mundial a una mayor velocidad que la registrada en períodos anteriores.

En este sentido, la estrategia de desarrollo no puede limitarse a buscar el desplazamiento posible con la onda de los distintos tipos de produclo en el espacio mundial y a vivir de las renlas acumuladas del know how del producto en cuestión. Más bien, se requiere insertarse flexiblemente en la producción mundial por periodos específicos de un determinado número de anos. La inserción es necesaria en los momentos de mayor rentabilidad, es decir, de auge el produclo y no en momentos de madurez y descenso del mismo para asegurar que se avanza y aprovecha paulatinamenle las etapas de vida del producto a nivel mundial. Debe buscarse un movimiento hacia adelante en el ciclo de vida del producto y no a desplazarse con el ciclo de vida porque esto orienla la competencia hacia menores niveles tecnológicos o hacia espacios mundiales más periféricos.

El caso del calé es un buen ejemplo aplicable al país, en el cual se está viviendo de "renlas tecnológicas" acumuladas de un produclo maduro o en decadencia. Aclualmente, el producto es rentable para el pais por las externalidades desarrolladas y por la experiencia acumulada con respecto a paises periféricos que están compitiendo con este producto como es el caso de los africanos. El producto puede continuar siendo rentable para el país por un período de tiempo, pero la rentabilidad es con respecto a los países más atrasados que lo está produciendo como "nuevo producto" y no, con los países más adelantados que lo está desplazando o sustituyendolo por otros productos más rentables y competitivos.

Esle concepto hace referencia más que a productos especílicos a una melodologia llexible de reinserción permanente en el mercado mundial. 
La nueva estruclura productiva replantea las masas mínimas críticas de capital rentables y eficientes de las plantas productivas, asl como una nueva estructura de relaciones entre empresas grandes y pequeflas. En ciertas ramas se elevará las masas mínimas crilicas de competilividad, pero en olras implicará una nueva reestructuración referida más bien al tamafio de empresas que se engranan entre sí en lunción de la competencia nacional y mundial.

\subsubsection{La conformación de Instanclas desburocratlzadas y descen- trallzadas nacionales de coordinación estratéglca entre go- blerno, unlversidades y sector prlvado}

Estos elementos implican y requieren una acción más concienle y organizada entre el sector público, privado y universidades, orientada hacia el mercado internacional y al mercado nacional. Requiere la creación o el desarrollo de instancias instilucionales con objelivos específicos de desarrollo. Partiendo de que habrá una mayor comunicación e inlegración entre ambos mercados, el nacional y el mundial, la planificación e investigación tecnológica deben estar vinculadas e integradas dentro del espacio nacional e internacional.

a) Un primer conjunto de acciones dentro del espacio de estas Ires fuerzas (gobierno, sector privado y universidades) debe ir orientado al conocimiento, sistematización e investigación del mercado de productos a nivel internacional en función de las posibilidades y potencialidades productivas del pais. En un esfuerzo de colectivizar los recursos para la invesligación y los resultados de esa investigación en función de todas las empresas. La investigación de mercado debe estar orientada a conocer y dimensionar las oportunidades del mercado internacional y nacional. Se requiere de una inslancia especializada en el estudio del mercado internacional en funcion de orientar a los produclores. Una instancia que a la vez que investigue divulgue y eduque a la opinión pública y a los partidos políticos de todo tipo.

b) El segundo conjunlo de acciones está orienlada a la investigación, desarrollo o difusión de tecnologias y a la creación y desarrollo de externalidades dinámicas. En un primer momento no se Irala de desarrollar tecnologías en abstraclo o nuevas lecnologias, sino más bien debe buscarse la obtención o consecución oportuna de ciertas lecnologias en función de las necesidades particulares del pais para participar en el mercado mundial. Este esfuerzo debe tener como paralelo la inversión en un plan global nacional de difusión de tecnologias en la planta productiva nacional. 
Los últimos estudios sobre ciencia y lecnologia han demostrado que más importante que el desarrollo de lecnologias propias es la capacidad de dífusión y adopción de lecnologias. Cienos paises caracterizados por ser adopladores de tecnologias han sobrepasado a paises que son innovadores de tecnologías. En este aspecto, ha sido delerminante el esfuerzo de consecución y de difusión. Esto es claro en sectores estralégicos como el hardware y el software en la industria de la informálica, la compulación o en la lecnobiologia. En esle aspeclo enlra a jugar un rol importante el desarrollo del sistema no formal de educación, tanto dentro del espiritu de este punto, como dentro de una política lecnológica y de transformación educativa a planlear posteriomente. Esla instancia debe de velar por la creación de oportunidades para la permanente actualización tecnológica de la inteligencia salvadorena. Se requiere una instancia de acción para la adopción de tecnologias con la finalidad de obtener por distintos medios, las tecnologias óptimas y difundirlas al interior de todos los sectores del pais.

c) El tercer conjunto de acciones está orienlado a la investigación y desarrollo del consumo, a la generación y desarrollo de nuevos productos que satisfagan las necesidades de consumo nacional, a los cambios en los patrones de consumo hacia consumos más óptimos y a la elevación de los estandares minimos de consumo. Por ejemplo, para desarrollar la demanda y el hábito de consumo de productos marinos en la diela alimenticia nacional es necesaria una campaña de educación que logre ampliar el mercado y que posibilite el crecimiento de la masa de inversión en la pesca, que a la vez abarale sus costos, amplie el consumo de proleina y desarrolle el complejo pesquero simultáneamente vinculado con la exportación (camarón, por ejemplo) y con el mejoramiento de la dieta interna.

El desarrollo del consumo tiene una influencia significativa en la competitividad de la producción nacional porque se orienla a acercar los niveles de exigencia mínimos de calidad de la producción nacional con respecto a la internacional. El desarrollo del consumo obliga a economías de escala en cuanto que se evita la dualización de la planta producliva que dilerencia la producción para la exportación de la producción para el consumo nacional. La dualidad de la producción y el consumo tiene en la práclica el efecto de ser una deseconomia de escala. La elevación de los estandares mínimos y conlroles de calidad permilen una plataforma de competitividad en el consumo y la producción orientada al mercado nacional e internacional.

Ahora bien, esta instancia para el desarrollo del consumo sobrepasa en su concepción y acción a las propuestas sobre los comités de delen- 
sa del consumidor en varios aspectos. Primero, en que no adopta una actitud pasiva y detensiva hacia la producción o meramente reacliva; segundo, en que considera a la producción y al consumo como hislóricas, es decir, como un binomio desarrollable, y, tercero, lo vincula estrechamente a la competitividad de la producción, es decir, estrechamenle vinculado a la estrategia para el desarrollo de la producción misma. En esle sentido, hay que diferenciar claramente la idea aqui expuesta sobre el desarrollo del consumo en su contenido y espíritu progresivo a la relativa a la defensa del consumo, en su concepción más estática y a veces regresiva.

Estas tres instancias instilucionales o unidades de acción interseclorial para la investigación y el desarrollo deben estar altamente vinculadas o conformadas por el sector privado, las universidades y el Estado y permitir la alta competitividad de las plazas para los recursos humanos en cuanto a salarios y prestaciones. Al respecto, excelente ejemplo es el Minislerio de Comercio Internacional e Industria del Japón (MICl o MITI).

No es que se pretenda crear más inslancias burocrálicas. Las formas orgánicas específicas, para el caso del país, pueden adoplar las más variadas modalidades de descentralización o basarse en la reestructuración de las inslancias exislentes. Lo que importa es asegurar la vinculación enlre universidades, sector privado y seclor estatal, en un esluerzo estratégico conjunto en el cual ninguno se poslule como elemento dominante por sobre los demás, sino que conjuntamente sean enles que polencialicen la aclividad producliva. En el caso del pais, uno de los problemas más graves al respeclo es la desvinculación orgánica y de acción entre estas Ires inslancias de desarrollo.

En el pasado, en América Latina se han creado inslancias gubernamentales que han derivado en organismos burocráticos desvinculados del sector privado y las universidades. Estas instancias no lienen posibilidad de ser efectivas y elicaces, sino es en intima vinculación con la empresa privada y las universidades. Deben lener una preocupación real, de intereses y de expectativas anle los problemas productivos generados en el mercado inlernacional y nacional.

Las empresas en el país para sobrevivir en este nuevo orden mundial, enirentan grandes desatios de carácler lecnológico y comercial que no encuentran respuesta a corto plazo. Los desalios ni siquiera han sido identificados y asumidos por las otras dos instancias. Es una limitante para la integración de esfuerzos que las dos principales universidades del pais tengan planleamientos dilerentes, contrapuestos y a veces de entrentamiento con respeclo a las instancias estatales y las unidades 
productivas. Por otra parte, las instancias estatales se ven como unidades normadoras por encima de las otras. Bajo estas circunstancias, to más probable es que cualquier esfuerzo institucional se convierta en instancias burocráticas enlorpecedoras del desarrollo. Debe rellexionarse al respecto el coslo de oportunidad que el mantener estas condiciones significa para el país.

Por úllimo, es necesario especificar que el sector privado se comprende en su acepción más amplia y en complementación de la sociedad política es decir del aparalo gubernamental. En este sentido, incluiria a las organizaciones del seclor laboral y las instituciones de desarrollo, según sea el caso, la oportunidad, la eficiencia y conveniencia.

\subsubsection{La ublcaclón de la Importancla de los planteamientos econo- micos micro/locales/reglonales.}

En la visualización de la transformación productiva, es decir, en la conformación de una nueva política industrial, se deben reconsiderar los esluerzos micro/locales, ya que es necesario que simultáneamenle a la estralegia nacional se busquen soluciones a los mercados locales 0 áreas geográlicas en la integración productiva a nivel micro. Estas experiencias adquieren validez y posibilidad de desarrollo dentro de una reesIructuración productiva nacional.

Un error que se puede cometer es tratar de elevar, como política productiva nacional, experiencias micro bajo una concepción de una atomismo produclivo comunal ampliado a nivel nacional en congruencia con un alomismo regional y nacional dentro del mercado mundial. Esta visión fragmentada del mercado nacional y mundial es perjudicial, reaccionaria y peligrosa ante las nuevas demandas y desalíos que enfrenta el pais ante el mercado mundial. Vinculado a estos planleamientos, se ubican las posturas reaccionarias con respeclo a la tecnologia.

Es necesario ubicar los planteamientos regionales de desarrollo en articulación con los complejos integrados. En este punto es posible rescatar el concepto de polo de desarrollo pero articulado dentro de la estrategia global con los complejos integrados. Con esto, es decir con la relación entre complejos inlegrados produclivos, polos de desarrollo y desarrollo regional se puede arribar a un sistema matricial produclivo que inlegre dinámicamenle el aparalo productivo potencializándolo en función de la compelilividad internacional y a las necesidades locales. 


\subsubsection{El desarrollo del aparato materlal de comunlcación y trans- porte.}

Por aparato malerial de comunicación se comprende todo el sistema de carreterras, de puertos, de lelecomunicaciones y en general lodo el sistema para trasportar hombres, materiales, mensajes e ideas. Su función en el aparato produclivo es integrarlo en el espacio y en el tiempo y de coordinar su desempefio. En un senlido más amplio, esto abarcaria el procesamiento de datos y dilusión de información. El retraso que al respecto enfrenta el pais se convierte en una de las mayores deseconomias, en todos los ámbitos de la producción, la inversión y el consumo, que le reslan compelitividad.

En EEUU es muy conocido el papel estratégico que jugó el ferrocarril y luego el sistema interestalal de carreterras en la inlegración y desarroIlo de ese pais. En El Salvador el sistema de carreleras del Norte (Chalatenango, Cabañas y Morazán) es lo mas retrasado, y en relación a la producción agropecuaria es un faclor de desventaja con respecto a otras ramas, sobre todo eri las áreas geográficas donde se ubica la pequena producción agropecuaria.

Adicionalmente, el sistema de teléfonos en su restricción cuantitativa y de calidad liene en la actualidad altos costos económicos para la producción y para los individuos. Eslo mismo ocurre con el sistema de transporte humano.

En estos punlos se debe tener un postura agresiva en lo que respecta al financiamiento internacional inmediato dentro del Plan de Reconstrucción Nacional.

Al hacer referencia a una estrategia productiva que replanlea la producción, que la reestructura, no debe ocullar el problema de la distribución del valor agregado. Esto es el otro aspecto para la viabilidad de cualquier modelo de desarrollo, que complementa los elementos de una politica industrial y que la hace sostenible en el tiempo. Un planleamiento productivo es viable y pertinente únicamente si conlleva los canales y estructura distributiva que asegure su reproducción material y humana asi como su eslabilidad en el tiempo.

Al respeclo deben criticarse dos posturas: la que percibe la producción como problema y oculla o rehuye enfrentar el problema del intercambio y la distribución, asi como la contraria, que enfatiza el problema de la distribución, creyendo resuelto el problema de la producción y orienta la producción en función de la distribución sin identificar que la producción liene sus problemas particulares y que la distribución está condicionada en su tamaño y posibilidad por la producción misma. 
Pero a la vez se da lo contrario. La producción únicamente es posible con la más adecuada distribución, entendiendo por adecuada lo que asegure a más largo plazo su reproducción y estabilidad. En consecuencia, planteamienlos económicos que sólo hagan énlasis en la producción o en la distribución, atentan conlra la misma seguridad del modelo de desarrollo del país. En eslas unilateralidades caen muy trecuentemente el GOES, por un lado, y el FMLN, por el otro.

Las cinco áreas anteriores componen la estructura básica para conformar una política industrial que persiga la reestrucluración productiva en primer lugar. Es claro que la especificidad de los complejos productivos inlegrados de reinserción inlernacional, o la identíicación y organización de los conjuntos de acciones institucionales o la ampliación de experiencias microlocales o la adopción de la llexibilidad como método rebasan las posibilidades de este artículo. Sin embargo, todos estos pueden convertirse en la plalalorma para una política global de investigación que formule una propuesta nacional más específica. En esto debe insistirse que una política industrial que persiga la reestructuración productiva, es decir del aparato productivo, está más allá de los conceplos tradicionales de reconversión industrial.

Por ejemplo, en el documento de la CEPAL sobre la reconversión industrial en Centroamérica, aún cuando es un buen esfuerzo de conjun10 y preliminar sobre el estado de la industria, implícilamente liene un enloque Iradicional al respecto. Se orienta más a identilicar la reconversión industrial con la modernización industrial. Ante esto, debe entenderse que el planteamiento que acá se desarrolla disla mucho de esta postura. Esto, sin embargo, no niega el aprovechamiento construclivo de esfuerzos de diagnóstico como el mencionado.

\subsection{El Incremento de la competltividad por medlo del Incremento de la productividad y no de la devaluación. La necesldad de una poiltica tecnológica.}

La competitividad se define como la capacidad de un producto de ser demandado entre otros por su precio, calidad o por sus caracteristicas pertinenles y adecuadas como salisfactor. El ámbito real de la compelitividad es el mercado mundial (que incluye el mercado nacional) en cuanlo que el desarrollo de las fuerzas productivas lienen como espacio ese mismo mercado. En cuanlo a la competitividad y su logro existen dos tendencias: la que se denomina estrategia espúrea y retrógrada y la denominada real o tecnológica.

La primera, la espúrea, tiene por un lado como lundamento el reducir 
los precios via constrenimienlo de los salarios reales, vía deterioro de la calidad del producto o vía degradación de los segmentos del mercado. La segunda es resultado de la reducción de los precios, la ampliación de los mercados en sentido vertical, el mejoramiento de la calidad del producto y el desarrollo del producto en general. Todo esto se logra vía incremento de la productividad de la fuerza del trabajo, de su nivel de calificación y de la eficiencia de los procesos productivos.

La primera vía es espúrea en cuanto que no ofrece soluciones reales y estables de competitividad via precios sino soluciones falsas suslentadas en la sobreexplotación de la mano de obra y en la represión política que esto genera. El deterioro del salario real, del poder adquisitivo de la población vía devaluación, es una agresión a los sectores laborales que necesariamente conlleva al levantamiento y la represión.

Una cosa es buscar el lipo de cambio electivo real, otra es la devaluación como instrumento preferente para la consecución de la competitividad. Aunque ambas en la práctica se puedan unir, su orienlación y fines las ubican en lados dilerentes. Suslentar la competilividad en mecanismos temporales, artificiales y regresivos históricamente es una concepción limitada de competitividad al igual que lo son los mercados protegidos, mano de obra de bajo costo, lasas de interés subsidiada, elc. (Véase Fajnzylber, 1989).

El incremento de la productividad como fundamento de la competitividad lleva a la delinición de una política lecnológica orientada al desarrollo, difusión y adopción de lecnologias en sus fases más tempranas que generan las condiciones de la producción mundial. Con respecto a ésto, es necesario lener claros los dos escenarios tecnológicos posibles en el fuluro inmediato. El primero de incremento del proteccionismo tecnológico y de incremento de las contradicciones entre los paises allamenle industrializados con los paises de reciente industrialización, y de éstos con respeclo al mercado centroamericano. Tal es el caso mexicano, en el que se puede prever su alta competencia con respecto al mercado centroamericano.

El segundo.es el de la disminución de las barreras de dilusión internacional de lecnologia. En ambos casos se abre un período altamente inestable vislo como oportunidad o como gran peligro para la producción nacional que requiere, por parte del pais, una politica tecnológica allamente agresiva y no dejada a la eventualidad. En esta perspectiva, el proyecto de creación de la Comisión Nacional de Ciencia y Tecnologia es un esfuerzo en la dirección correcta. Habrá que conocer mayores detalles en cuanto a su organización y líneas de acción para juzgar su pertinencia. 
En todo caso es necesario la definición de una política tecnológica en función al nuevo periodo, a la compelitidad nacional e internacional. Al respecto debe comprenderse que delrás de la competitividad de un determinado produclo no sólo se encuentran procesos lécnicos de una unidad productiva, sino la articulación social en las cuales se pone a prueba la pertinencia histórica de la sociedad como sistema.

"A nivel nacional y con una perspectiva de mediano y largo plazo, competilividad implica capacidad para sostener e incrementar la participación en los mercados internacionales, con una elevación paralela del nivel de vida de la población. A corto plazo la devaluación mejora la posición relativa de las empresas de un país; pero, intenlar enfrentar el tema de la competilividad sobre la base de una secuencia de devaluaciones que sustituyan el aumento de la productividad y la incorporación de progreso técnico, conduce a erosionar la cohesión social comprometiendo, en último lérmino, la propuesta de lavorecer la inserción internacional." (Fajnzylber, 1989, p.103).

Obsérvese que el planteamiento de devaluación entra, por otra parte, en contradicción con el desarrollo del consumo planteado anteriormente. Más bien, el incremenlo de la competilividad por la productividad supone un mejor consumo y un acercamiento entre consumo nacional e internacional, asi como una trantormación de la luerza de trabajo en su calificación y educación en general (Véase SELA, 1988).

\subsection{La revolución educatlva.}

Para ubicar la dimensión de la tarea a realizar en el ámbito educativo, no basla el término de reforma educativa, es necesario uno que connole una mayor profundidad, el de revolución educativa. Los cambios en la estruclura del conocimienlo humano y más que eso, en la plétora de información y nuevos conocimientos técnicos y científicos en los últimos años, implican y requieren necesariamente cambios en el aparalo de educación y en la curricula nacional. $Y$ no sólo eso, sino también un esfuerzo de aclualización de la generación presente que ocupa el lugar de inteleclualidad y dirigencia política nacional. Esta ha sido educada en un sistema y método de educación del período anterior, con conocimientos básicos que actualmenle son obsoletos. La imporlancia de la educación en la Iranstormación productiva ha llevado ha ciertos autores e instituciones como la CEPAL a postularla como el eje de la transformación producliva. (Véase CEPAL, 1992.).

La imporlancia fundamental de la educación para el desarrollo económico se ha convertido en un redescubrimiento constante de algo que todos sabemos y que nunca se logra comprender en su verdadera magnilud. Lo más importante en eslos momentos es el redescubrimiento de 
la educación en general y de la educación básica en particular, no únicamenle como derecho social, sino como iundamento para el desarrollo de la productividad, la producción y la convivencia política y social.

Anteriormente se vinculaba la educación superior y media, a la producción, asi como la formación protesional y vocacional, en cuanto que éstas se percibian inmediatamente vinculadas a la productividad. Actualmente, se han superado estos niveles inmediatos de la comprensión de la educación llegándose a concebir la educación básica como el fundamento de la productividad nacional porque se reconoce que ésta, la educación básica, proporciona la estructura fundamental y las habilidades generales de razonamiento del grueso de la población trabajadora que por lo general escasamente logra completar esle nivel educativo. La educación básica es la que posibilita el nivel de impacto de los siguienles niveles educativos. La calidad de la educación básica condiciona el éxito y la cuantia del aprovechamienlo de la formación en los niveles subsiguientes.

La intima vinculación entre educación y productividad no es únicamente una lección aclual, sino una lección histórica. Los éxitos en la producción de lodos los paises conocidos y en la reinserción conveniente en el mercado mundial, han tenido como precondición en sus tases iniciales, revoluciones en el aparalo educativo. Estados Unidos, Europa y los cinco NIC asiálicos son ejemplos clásicos, sin embargo ninguno se puede comparar en su ejemplo aleccionador con el caso del Japón:

"Un hecho menos conocido pero probablemenle más importanle para el éxito continuo del Japón, fueron los extraordinarios cambios introducidos en el sistema de educación. Al comienzo de la era Meiji, sólo el $15 \%$ de la población sabia leer y escribir, pero en 1872 se había eslablecido un sislema obligatorio y universal de enseñanza elemental y se habían sentado las bases de la enseñanza secundaria. Tras cuidadosas investigaciones, se tomó la decisión de basar el sistema de educación en el sislema francés de distritos escolares y el sistema universilario en el de Estados Unidos. La lasa de asistencia en el nivel primario aumentó de menos del $30 \%$ en 1873 a más del $90 \%$ en 1907 . El número de escuelas secundarias se decuplicó en el período de 1885-1915. Por el nivel de educación de su población y por la imporlancia asignada a la educación, el Japón pasó a ligurar entre los primeros países del mundo. Para lograrlo se requirió gran conslancia y determinación. El Japón destinó invariablemente a la educación un porcentaje mayor de su producto interno real que cualquier otro país europeo o asiático". (Banco Mundial, 1991, p. 67).

Aclualmente, Japón registra el indice combinado más alto de desarrollo humano y la proporción más alla en el mundo de científicos y técnicos por cada mil habitantes: $317 / 1,000$, siendo sus más cercanos contendientes Austria con 268/1,000 y Suecia con 262/1,000 (PNUD, 1991). 
Esto contrasta signilicativamente con el caso de El Salvador que registra una proporción de 1.4/1,000 (lbid.)

Esle ejemplo persigue orientar sobre to fundamental de una revolución educaliva para una verdadera translormación productiva, es decir, la intima vinculación entre la transiormación induslrial, del agro y de los servicios exigen elevar los niveles de educación básica y los cambios de su calidad. Se pueden poner como ejemplos los cullivos de alta productividad en el agro de Taiwán y de nuevo se encuentra como fundamento el nivel educativo alcanzado en eslos países. El éxito de cualquier translormación agraria, incluida la reforma agraria salvadorefía, tiene como condición necesaria la elevación sensible y sostenida de los niveles educativos de la población.

En El Salvador, esta revolución tiene dos desalios o ejes de transformación real. Por un lado, la extensión y por otro su calidad. Es una exigencia incrementar la cobertura educativa, especialmente en el agro. Esto requiere una transformación de la estruclura cuanlitaliva de los diferentes niveles que requiere la búsqueda de la óplima relación en la asignación presupuestaria para cada nivel educativo.

Escolarldad promedio de la PEA por rama de actlvidad economlca

$E P B$

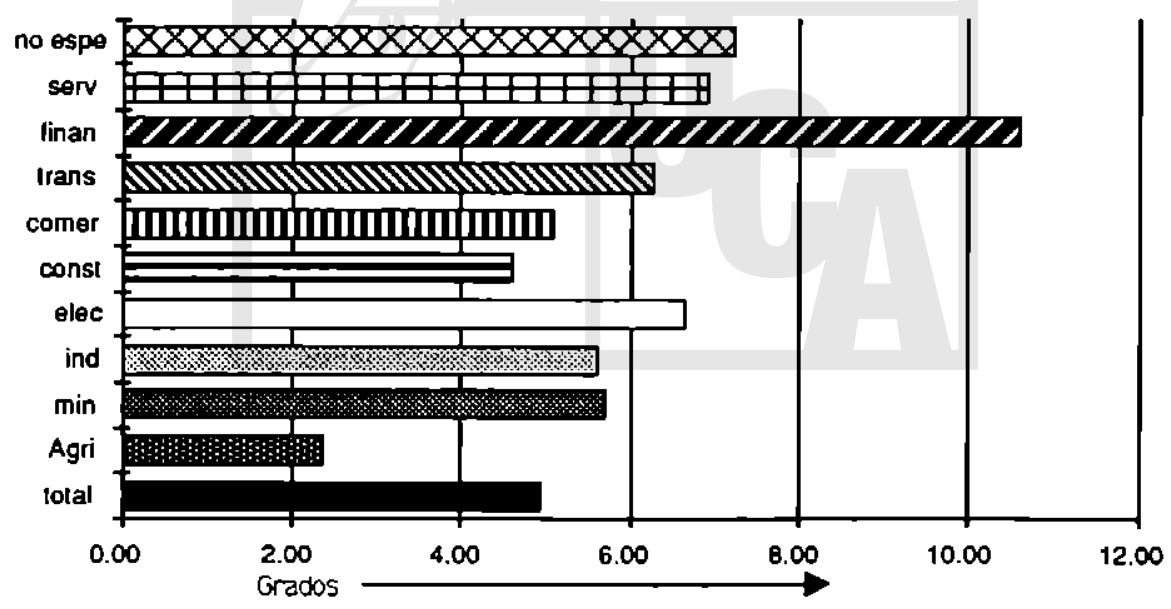

Fuente: elaborado en base a FUSADES (1989). 
Enfrentar los grandes desafios mundiales e impulsar una verdadera transtormación productiva, incluyendo la elevación de la productividad en el agro, será imposible con los acluales niveles educativos de la fuerza de trabajo. En el país, que la PEA tolal tenga una escolaridad promedio un poco menor a quinto grado (4.95 grados) y que la PEA agropecuaria regisire un poco más de segundo grado (2.37 grados) (FUSADES, 1989), además de las implicaciones sociales que en si mismo reflejan, representan un cuello de botella para el desarrollo nacional y para la reestructuración productiva.

Por otro lado, es necesaria una reforma de la currícula educativa, es decir, una transformación de la calidad de la educación, entendiendo por eslo no el que sea mejor o peor, sino que la educación responda a las transformaciones produclivas y sociales que se está llevando a cabo en EI Salvador.

En nuestro país, se están Iranstormando las esiructuras económicas y políticas y si esto no se acompana de la correspondiente transformación de la currícula educaliva, tal como se ha explicado anteriormenle, la sostenibilidad y el impacto efectivo de los cambios no se asegura en el tiempo. El aclual sistema educativo que se originó con la reforma educativa a finales de los sesenta, corresponde a una concepción productiva ya superada, orientada y en congruencia con una estralegia de industrialización por sustiluciones de importaciones.

Más aún, la relorma educativa pasada nació extemporáneamente, es decir se inicio el proceso de relormas educativas en función del modelo de sustitución de importaciones cuando este se agolaba. El mayor defeclo de la anterior reforma radica precisamente en su falta de oportunidad; su real inserción y necesidad histórica se ubicaba en la década de los cincuenta y no veinte ańos después. Esle deslase histórico entre educación y producción, que cometieron las generaciones pasadas en nuestro país es una lección para las generaciones presenles que deben evitar comeler el mismo error.

Para reformar la educación se requiere, por parte de las entidades políticas y las más diferentes organizaciones sociales, sobrepasar la dimensión humanistica de la educación. Se hace necesario no concebirla únicamente como un derecho del ser humano, sino como una necesidad del nuevo aparalo produclivo y político para su sobrevivencia y su reproducción. No es únicamente la fuerza armada y la escuela militar la que debe cambiar su doctrina y su sistema de ensefianza; es fundamenlalmente loda la sociedad salvadorefía. En este punto, los acuerdos de Chapultepec carecieron de alcance y talante histórico. 
La curricula del pais no puede contormarse en base a valores absIractos sobre to que debe ser el ser humano, sino que primeramente sobre la necesidad de sobrevivencia nacional, en cuanlo a las necesidades específicas que deben satislacerse considerando el nuevo orden mundial. La educación y la currícula deben responder a la gran estrategia nacional y global de desarrollo entendiéndola en su más amplio concepto, y vinculada fuertemente a la reproducción de la base nalural sobre la cual se rige loda la actividad socieconómica.

Unicamente asegurando, por medio de la educación, la conciencia de todos los individuos sobre la relación de producción/educación, producción/medio ambiente, producción/distribución elc. es que se asegurará la sostenibilidad del modelo de desarrollo en el país.

En este sentido, la posibilidad de realizar la transformación productiva, asi como lodos los puntos anleriormente mencionados, lienen como requisito la revolución de la educación de El Salvador. Entre más prolunda sea esla revolución educaliva, mayor impacto y profundidad tendrán las transformaciones produclivas y los alcances y resultados de las actuales transformaciones del modelo politico y económico serán mayores en el tiempo. Las características del nuevo periodo hislórico que estamos construyendo para los próximos cuarenta años, se definirán en los próximos dos afios en relación a la capacidad de visión de la actual generación.

En cuanto a la óptima relación entre los diferentes niveles, se requiere una visión realista sobre la ulilización eficiente de los recursos invertidos en educación. La naturaleza estratégica de esta implica la identificación de líneas minimas y fuentes de tinanciamiento presupuestario. A la vez, implica un cambio en el engranaje de lodos los niveles y en la orientación y vinculación de la educación universitaria con las aclividades produclivas. En particular, se requiere una evaluación de la mediocrización de la educación y el oporlunismo con el surgimiento de lantas universidades privadas. También se requiere la transformación del caslillo de martil en el que las universidades se han desenvuello convirtiéndose en enlidades desvinculadas de la actividad productiva colidiana.

La educación universitaria no debe ser concebida por encima de la actividad inmediata, o que se acerca a la actividad inmediata a partir de la actividad suprema. Lejos de esto, la educación universitaria podrá ser relevante y pertinente en la medida que se vincule a la aclividad productiva y práctica, no en conceplo o como requerimiento de horas sociales, sino como parte de la curricula para el alumno y para el docente.

En cuanto a la conformación curricular, la aclual desvinculación entre instituciones de la sociedad civil, gobierno y empresa privada, por un 
lado, y universidades, por otro, es la principal explicación de la mediocridad y lo superfluo de la aclual educación universilaria, asi como de su escasa relevancia e incidencia en los grandes momenlos actuales. La UCA y la UES deberian, de una forma realista y honesla, evaluar su incidencia en el actual desenvolvimiento de la coyuntura histórica y replantearse una transformación estratégica de cara al luturo de nuestro país. En todo caso, la historia juzga a los dos centros más importantes de educación en el pais por sus aportes concretos. Cuando se ha planleado la necesidad de una reforma educativa obviamente se incluye a la educación universitaria pública y privada, y no únicamente al sislema lormal de educación en manos del gobierno.

Es interesante observar como los economistas del pais están educados y más orientados a una actividad macroeconómica formal y no hacia la esfera real de la economia. Se tiene poco conocimiento sobre la planta y actividad productiva de EI Salvador. Los conocimientos son generales y se orientan hacia la eslera virtual de la economia, más hacia lo monelario. lo comercial o hacia la actividad estatal y no hacia la actividad producliva real. Con eslas distorsiones, los prolesionales ayudan poco a desarrollar la actividad producliva.

Lo expresado anteriormente sobre las características y magnitud de la revolución educativa, carece de sentido al no reconocer el papel que asume uno de los principales agentes del proceso educativo: el docente. Al respecto, sería idealisla el soslayar la situación socioeconómica actual de ésle. Al docente, para su ejercicio profesional, con un salario medio interior a muchos obreros fabriles semicalificados, se le requiere una adecuada vestimenla, que contribuya con su salario al financiamiento de los recursos, elc. Es cuestión mínima de administración de recursos humanos la adecuada remuneración y disponibilidad de recursos para la ejecución de las tareas. Sin embargo, el entorno en el que se deselvuelve el docente no puede ser sino calificado de insuficiente. El incremento sustancial del salario docente es cuestión tan básica como la renovación curricular. Este conceplo sobre el papel cardinal del docente es necesario reconocerlo independientemente de la postura de ANDES ya que el docente, dentro de la administración pública, debería ser el prolesional privilegiado como sector mejor remunerado y con mayores prestaciones. Eslo por la sencilla razón de que en sus manos se forja el recurso humano del pais, el hombre salvadorefio real del luturo. Adicionalmente, es también necesario sehalar, críticar y modificar la poslura inmediatista reivindicativa de ANDES, que más allá de los intereses particulares del gremio, debería involucrarse en el compromiso de la revolución educativa, haciendo propuestas desde su óplica ejecutiva. 


\subsection{La modernización estatal y el marco Juridico-productivo}

El Estado salvadoreño aclual en su estructura básica se encuentra en transición, entendiendo y asumiendo ambos componentes del Estado, la sociedad civil y política. El Estado está cambiando y es necesario hacer de esle cambio una actividad conciente y orientada por la sociedad ante la necesidad de transiormar toda la actividad productiva y civil en función de la sociedad que se eslá construyendo.

El Estado, en cuanto sociedad política, está cambiando la forma de relacionarse con la sociedad civil y la aclividad productiva misma. Cuando se habla de un cambio eslatal se plantea la necesidad de modificar su estructura, es decir, su organización, de cambiar sus componentes y el peso específico de cada uno de éslos, así como redelinir sus funciones con relación a la nueva estructura producliva.

En principio, esto implica cambiar la función de actividad regulaloria y el marco jurídico económico. Se debe partir reconociendo que el marco juridico regulatorio actual corresponde a la esinuclura productiva del período anlerior, lo cual hace que el marco aclual sea incoherente con la nuevas demandas de estructura productiva que se pretende desarrollar o las nuevas realidades mundiales.

La aclividad regulatoria viabiliza premeditadamente la aclividad económica. Sin embargo, el problema se presenta cuando la aclividad regulatoria no corresponde a las actividades que se pretende desarrollar. Lo que hace el neoliberalismo aclualmente es desregularizar las actividades creando condiciones para la redelinición de las funciones y la modernización de la organización del Eslado. El neoliberalismo se ha puesto de moda porque encarna la necesidad histórica con respecto a la transformación estatal, pretendiendo destruir un marco regulatorio y la antigua injerencia estatal. Sin embargo, es previsible que al cambiar las necesidades y coyunturas se plantee de nuevo un marco regulatorio más adecuado, que será válido hasta que las nuevas condiciones exijan nuevamente una redefinición.

Por otro lado, es necesario el cambio del insumo/producto e insumo/ funciones porque ha cambiado la actividad del Estado. A nuevas funciones es necesario plantear nuevos recursos o la relocalización de los mismos para que se adecuen a los cambios. Esto implica necesariamente cambios en la composición y tamaño del empleo público. Desaparición de instiluciones y creación de otras.

La modernización eslatal es necesaria enlendiéndola no únicamente como eficiencia en su aclividad. Esta modernización no es sólo en cuanto a sus funciones y productos sino también en sus ingresos y gastos. Lo 
primero significa modernizar la recaudación tributaria y lo segundo la modernización del gasto fiscal.

La otra cuestión es relativa a la descentralización y privatización. EI gobierno de Duarte enfalizaba la descentralización y participación comunal, el actual la privalización. Es necesario identificar la necesidad histórica que subyace en estos conceplos, que, aunque reflejan o podrian reflejar marcos ideológicos distintos, buscan realizar una tendencia histórica de Iransiormación y de búsqueda de optimización de los recursos del Estado para hacerlo más eficiente.

Más allá de los términos; se puede identificar la tendencia y necesidad de la participación de la sociedad civil en la normación y regulación de la actividad gubernamenlal y en la actividad regulatoria misma. El aparato gubernamental se ha desarrollado a tal grado que no logra ser eficiente en su actividad regulatoria. Por ejemplo, el Ministerio de Educación no logra regular y normar todas las actividades educalivas, to cual hace necesaria la participación de la comunidad en la administración de los recursos y de entes de la sociedad civil, llámesele a eslo privatización o descentralización.

Debe asumirse un concepto amplio de privatización o participación buscando reflejar en él la necesidad de buscar la transferencia del poder eslatal a las instancias civiles y en contraposición, buscando limitar sus funciones y actividades a aspectos normativos. Esto es positivo independientemente de denominar la privatización o descenlralización, o participación de las ONG. Se ha entrado en una polémica de lérminos que debe superarse para identilicar y reconocer la importancia de la redefinición y ampliación de espacios en la participación de la sociedad civil.

En esta nueva relación entre sociedad civil y sociedad política en la relación y participación con la base económica, se encuentra toda la nueva vertiente para la creación de los nuevos modelos económicos y metalenguajes actualmente en crisis. Muy probablemente del desarrollo teorico en esta relación es que surjan los nuevos paradigmas para la izquierda latinoamericana.

De lo anterior se deduce la imporlancia de cambiar la relación entre la sociedad política y sociedad civil entendida como todas las instituciones privadas, no gubernamentales, de desarrollo, organismos politicos. Las dos esferas del Estado constituidos por la sociedad política sociedad civil en su relación con la sociedad económica (gremios empresariales y sindicales y cooperativos), deben cambiarse en sus relaciones para eslablecer un Eslado con una relación basada en una redefinición de funciones 
que cada una de ellas debe asumir. Debe existir una redefinición de los espacios de control e injerencia de cada una de ellas; 10 que anteriormente se consideraba como espacios de acción y control gubemamental o privado debe adaptarse al nuevo periodo. Por ejemplo, en acciones de investigación debe redefinirse la participación de los tres agenles buscando la optimización de los aportes.

El marco jurídico, que regula la actividad dentro de un marco economico en el que están definidos los agentes de la producción y distribución en los acuerdos de Chapultepec se orienta más a regular los derechos civiles y políticos de los ciudadanos. Está más orientado a la actividad política necesaria. Su gran vacio son los acuerdos económicos. Sería autoengañarse el creer que este vacio es producto de la carencia de liempo o de un pragmatismo en la negociación. El vacio de los acuerdos económicos proviene de un vacio de estrategias económicas que hasla la lecha tienen ambos agentes. El cambio de las lormas de propiedad no son en si misma una estralegia de desarrollo, a lo sumo son condiciones. Más allá de los acuerdos, sigue vigenle la necesidad e importancia de construcción de un nuevo marco regulatorio económico que debe basarse sobre calidad de produclos, derechos sindicales, competencia, etc. Sin embargo, en la práctica eslo ya se está dando.

Deben crearse instancias de fiscalización orientadas a combatir ineticiencias y corrupción estatal. Esto no debe concebirse únicamenle como escape de produclos o apropiación de la propiedad colectiva, sino como una actividad que degenera la actividad estatal. El dafio no es que la persona se apropie de recursos; el dano es la asignación de recursos a actividades inelicientes o que se corrompa la eficiencia por los efectos dahinos de la cornupción.

Realmenle, una sociedad demuestra su decadencia en función de los niveles de corrupción que existen, sea ésla una dictadura o una democracia. Una sociedad es débil cuando un ciudadano para demandar un servicio normal ante el Estado, que es de su compelencia proporcionario, tiene necesidad de corromperse y corromper. Cuando se necesita el soborno para que se ejecuten los servicios, el Estado demuestra su debilidad en lodos los niveles. Las crisis de las democracias representalivas como lormas de estado se han vinculado fuertemente con la cornución, no únicamente con los casos recientes de Venezuela y Perú, sino como en proceso es el caso de Cosla Rica o en el pasado remoto como es el de Julio César y la transición de la democracia al imperio en Roma.

En El Salvador se ha cambiado en términos efectivos la estructura de poder y la misma Constitución. Estamos anle el surgimiento de un nuevo bloque en el poder, de una nueva estructura hegemónica y una nueva 
Asamblea Constituyente. En términos reales, no formales, existe una nueva Asamblea Constituyente. Si se ubica en sentido real, la Constitución es el acuerdo entre las diferenles fuerzas políticas de la sociedad en un marco de consenso sobre el que van actuar según los intereses y fuerzas de cada uno; esle marco posibilita no destruirse mutuamente y asegura la reproducción de la sociedad.

La existencia de una constitución real establece un pacto, un equilibrio de fuerzas sobre un contexto determinado que cuando es quebrado exige un nuevo marco que regule la actividad de las fuerzas en la nueva situación. La constitución es precisamente el marco que va cambiando estas regulaciones; anteriormente, se daba la exclusión de luerzas de importancia en la vida nacional. Actualmente, se ha constituido un nuevo espacio para la redetinición del marco constitucional.

Todas las nuevas instituciones del Estado deben rellejar y operativizar la confluencia de fuerzas entre los diferentes intereses que permilan una revolución estatal. Eslamos ante la realidad de una revolución política en proceso que beneficia a toda la sociedad, y en la medida que esto suceda, se garantiza la pacílica revolución política que se desarrolla actualmente

Las instituciones son la concreción de una relación o conjunto de relaciones entre diferentes elemenlos, es decir, son la suslantivación en el sentido de personificar en un ente una relación o confluencia de relaciones. Una institución refleja las fuerzas y relaciones entre ellas. Se debe insistir que las nuevas necesidades que se le presentan al Estado deben reflejarse en las instituciones. El dinamismo y no fosilización de las instiluciones estriba en la capacidad de dar espacio a las nuevas fuerzas emergentes o en el poder reflejar el cambio que se eslá dando entre estas.

Al respecto, es interesante de nuevo el Ministerio de Comercio Internacional e Industria del Japón (MICl o MITI), al cual la empresa privada - los diferentes agenles económicos lo perciben no como instancia externa a su actividad, sino como una instancia colaboradora y beneficiadora de su actividad. Los intereses de las dislintas ramas económicas se expresan en el $\mathrm{MICl}$, en el que se registran lodas ellas con su producción y aclividades. Eslo pone en evidencia la forma como la actividad estalal se orienta a la producción y como la aclividad de formación responde a la producción.

En sentido amplio, el Eslado incluye a los partidos y organizaciones políticas y al relerirnos al cambio eslatal es necesario enlalizar también la necesidad del cambio y práctica de los partidos políticos. Será intere- 
sante ver como éstos se adecúan, no sólo al nuevo momento político nacional, sino a las nuevas necesidades hislóricas de la nación. Por ejemplo, ARENA, PDC o el FMLN tendrán en el futuro inmediato, el desafío y la necesidad práclica de reestructurarse como partidos reales, tanto en su conformación interna como en la relación con los diferenles organismos de la sociedad civil. Ningún partido hereda o tiene como patrimonio de por vida la reprentación de ciertos grupos sociales. La historia es implacable: o se transforman o terminan como cascarones, surgiendo nuevas instancias que representen más adecuadamente los nuevos intereses y tendencias.

\subsection{La superación del problema de la tenencla de la tlerra}

Es necesario partir de las lecciones hislóricas en el pais y la registrada en otros. Con respecto al país, la estructura de la tenencia de la tierra fue un marco que estuvo presente y que obstruyó, condicionó y limiló el desarrollo en el anterior periodo. La forma de la tenencia de la lierra fue la base primaria del desarrollo de la guerra, que se ha basado en un componente fundamentalmente agrario. La guerra se condicionó y fundamentó en la concenlración de la lierra, aunque posleriormente se expresó en la lalla de inslancias políticas que dieran cabida y representaran las diferentes fuerzas y dinamizaran y equilibraran la estruclura de fuerzas.

La reforma agraria en parte ha solucionado el problema. Sin embargo, es claro que esto aún continúa siendo un problema en el pais y mientras no se resuelva, pone en peligro permanentemente los acuerdos de paz y la viabilidad y éxito de un nuevo modelo de desarrollo.

Una cosa es idenlificar el problema y otra es la forma como solucionarlo. Debe tenerse como premisa que eslo es un problema real que está en el origen y que limita el desarrollo en el país. A diferencia de lo que creen algunos seclores, no se tiene el tiempo necesario para solucionar el problema. Este debe ser entrenlado de inmediato para solucionar uno de los mayores relos para la producción y la productividad. La forma de la tenencia de la tierra no se ha superado y esto limila la productividad. Eslo es un problema de realidades y no de voluntades.

También debe partirse de la experiencia internacional de Japón, de Corea, de Taiwán y los mismos EEUU y Europa, que oportunamente dieron solución al problema de la lenencia de la tierra. Si se desea consinuir una sociedad moderna, menos conflictiva, es fundamental superar este problema generador de conllicto. Esto significa que si se liene objetividad y consenso sobre eslo, deben buscarse canales y formas del 
menor coslo sociable para todos los sectores que tienen vinculación con el problema.

Es necesario establecer diversos mecanismos que agilicen y dinamicen el mercado y las formas de tenencia adecuadas a la nueva estructura productiva que se desea desarrollar.

En la lenencia de la tierra, deben considerase al menos tres elemen10s: el primero es el ecosislema, es decir, no se pueden crear formas y tamafios de tenencias que agraven el problema del ecosistema y deterioren la productividad de la tierra, atentando contra este recurso estratégico. El segundo elemenlo a considerar es que, en la produclivdad y la producción, debe buscarse la forma de lenencia que sea más eficiente y productiva. Y, el tercero, que es cuestión de realidad, es la de superar la explosividad sociopolítica en el campo, es decir, es necesario que se distensione la distribución del valor agregado agricola, lo que significa dar al campesino mejores condiciones de acceso a la tierra y de remuneración salarial al jornalero.

Las condiciones de máxima productividad en la tierra está vinculada a la educación y comunicación en el agro; si se desea incorporar cullivos de alla produclividad en el agro, eslo liene como condición elevar el nivel educalivo de la población en el campo.

No se puede argumentar conlra las medidas de redistribución de la lierra adopladas en la década pasada, cuando no se ha dado la oporlunidad de elevar el nivel educativo para que la población pueda administrar mejor sus recursos. Si una reforma agraria no se acompana de esluerzos educalivos que eleven su produclividad, el hacerla establece los precedentes para su tracaso. Esta es una de las deficiencias de la reforma agraria actual, que no buscó elevar considerablemenle el nivel educativo en el agro para mejorar la capacidad administrativa y técnica. Adicionalmente, se encuentra el problema del acceso al crédito y el sistema de comunicación con respeclo a estas áreas geográficas.

En perspectiva del futuro, el problema económico de todo el sector agropecuario no se reduce únicamenle a la tenencia de la lierra. Una política hacia ésle sector, integrada dentro de una estrategia de reestructuración productiva, no se podría limilar a tal aspecto. Necesila incluir el elemento del crédito, el acceso y la difusión tecnológica, el sistema de comunicación, elc. Sin embargo, el desarrollo estratégico del agro y de lodo el pais liene como base el resolver definilivamente y de una vez el problema de la tenencia de la tierra. Y por hoy es en este punto, la tenencia, en donde de una vez se debe resolver lal limitación de desarroIlo. Este problema es tan obvio que no debería ser únicamente 
visualizado y planteado por los sectores de izquierda, sino a la vez ser asumido responsablemente por el sector empresarial.

En esta perspectiva, poco favor le hace la ANEP al país al adoptar una postura de obsinucción y problemalización en el problema de la tierra. Más bien, la ANEP eslá adoplando una postura conlraria a la historia ya que ese problema tarde o temprano se lendrá que superar. Es aleccionador cilar las palabras del ex-Ministro de Economía y Hacienda y asesor presidencial de Taiwán, en su arlículo recientemenle publicado en la revista Industria, de la Asociación Salvadorefia de Industriales (ASI):

En los años cincuenta, el sector agrícola dominaba la totalidad de la economía. Por consiguiente, en el transcurso del desarrollo, se asignaba prioridad primero al sector agrícola, luego al sector industrial y por último al sector de servicios. Otra importante razón para hacer hincapié en el desarrollo del sector agrícola fue la lección aprendida como consecuencia de la inhabilidad de resolver los problemas agrícolas en la China conlinental, que fue una razón clave por la que los nacionalistas perdieron su conflicto con el partido comunisla chino....

"Durante los años cincuenta y parte de los sesenta, la relorma agraria había sido un instrumento eficaz para la promoción del desarrollo agrícola de Taiwán. La relorma agraria, que es la redistribución de la propiedad de la tierra a los cultivadores de la misma, no sólo aumentan los ingresos de los cultivadores sino también tiene su propio significado social y polílico. La relorma agraria en Taiwán se llevó a cabo en tres elapas planificadas. La productividad de la tierra aumentó del $100 \%$ en 1950 al $121.5 \%$ en 1955 , mientras que la productividad de la mano de obra aumentó del $100 \%$ al $113.2 \%$ durante el mismo período. Empero, los intereses de los terralenientes no lueron desatendidos del todo. Se les permilió tener el equivalente de hasta tres hectáreas de tierras de arrozales de calidad media, y también recibieron compensación del gobierno, de la cual el $70 \%$ lo recibieron en bonos de arroz del gobierno y el $30 \%$ en acciones en empresas de propiedad del gobierno.

La ejecución exitosa de la relorma agraria ha solidificado la piedra lundamental del desarrollo agricola de Taiwán y ha ayudado a estabilizar las condiciones sociales y políticas. En los años cincuenta, el promedio de la tasa de crecimiento anual de la producción agrícola fue del $6 \%$, mucho más alto que en décadas más recienles. Además, este logro lambién habría proporcionado un ámbito propicio para el desarrollo del sector industrial. (Industria, № 37, diciembre 1991).

Respecto a las formas de propiedad de la tierra, debe entenderse que están en función de los procesos de producción. Son los procesos y modos de producción los que delerminan las formas de propiedad más adecuadas a cada proceso. La producción es quien delermina y transforma las formas de propiedad y al transformarlas hace aparecerlas como 
la base del proceso de producción. Acá debe idenlificarse que el problema no es la forma de propiedad que varia y se adecúa a la transformación del proceso produclivo. La propiedad de la tierra aparece como la base del proceso productivo, pero en su origen la lorma de producción Iransiorma la forma de propiedad y la pone como su base.

Esto es diferente a percibir las formas de propiedad como precondición de las formas de los procesos productivos. En esle sentido, las formas de propiedad, los tamanos de las unidades productivas y la forma como se vinculan los agentes produclivos vienen determinados por la estructura de producción, entendiendo ésta como los niveles lecnológicos y los tipos y ramas que se realizan en la producción. De nuevo, dentro del nivel tecnológico no entra sólo la maquinaria sino el nivel de educación y calificación de los individuos.

Sobre el problema de la tenencia de tierra debe tenerse una actitud práclica, identificando el monto de las lierras y su ubicación y producción para buscar formas de transacción y de Iransferencia de propiedad viables. Ahora bien, debe insistirse que la torma y esiructura de tenencia de tierra debe adecuarse a la transformación productiva planteada anleriormente.

El cambio de tenencia no puede ser un valor en si mismo, sino un marco base para la transformación producliva en el agro. Debe entenderse como transformación productiva en el agro la translormación lecnológica, de tipos de produclos, de niveles de procesamiento de productos, de relaciones insumo/ producto entre las dislintas ramas agrarias, y del producto orientado hacia el consumo interno humano, al productivo, así como hacia el mercado inlernacional.

\subsection{La modernización de las relaciones obrero/patronal}

Un problema y desalio estratégico que enfrenla el pais es cambiar las relaciones obrero-empresariales, lo cual significa que ambos polos cambien para que cambie la relación.

Lo anterior implica, por una parte, una modernización de la concepción y del papel del sindicalismo tanlo en la derecha como en la izquierda. Históricamente, los sindicatos y gremios se cargaron y asumieron más funciones politicas como consecuencia de los escasos espacios para las inslancias partidarias. Redelinidos los espacios las funciones deberan de redistribuirse. Los sindicalos no son partidos u organizaciones políticas de una determinada tendencia, sino más bien son inslancias económicas necesarias para formar el verdadero valor de la fuerza 
de trabajo de esla manera; son instancias necesarias dentro del mercado laboral. No es una fuerza que distorsiona el mercado de trabajo; más bien, es una fuerza que contribuye a su equilibrio y regulación. Se deben, entonces, superar, en el lado patronal, las visiones arcaicas del sindicalismo, y en el movimenlo laboral, debe identificarse y precisarse el sindicalismo, diferenciándolo de la actividad partidaria.

La modemización de las relaciones obrero/palronales, no se limita a la libertad de asociación de los trabajadores, orientadas únicamenle a la distribución del produclo generado. Esla es una visión reducida sobre lo que debe ser una nueva relación obrero-patronal. Esla nueva relación debe iniciarse en la misma actividad productiva.

Es necesario entender y tener una actitud práctica para identificar nuevas formas de colaboración. Los nuevos conceplos sobre administración de la producción (APYO) como calidad lotal , cero defectos, circulos de calidad, etc, lienen como fundamento una concepción diferente e integradora entre el obrero y el patrono. Es imposible exigirle calidad total al trabajador sin modilicar la actilud del patrón respecto al trabajador. El defeclo de muchas empresas al exigir nuevos conceptos es que ellos mismos no dan un nuevo conceplo sobre el trabajador.

Muchas veces se pretende adoptar y traducir conceptos productivos de la experiencia japonesa, sin considerar que éslos reflejan una particular realidad y concepción de estas relaciones. Se quiere importar el concepto sin la correspondiente relación obrero/patronal que existe en Japón. Uno de los éxilos de Japón es precisamente la capacidad de consenso obrero/palronal y la fluidez de la comunicación entre ambos. En nuestro caso, la relación obrero/palronal se percibe como relación antagónica en el proceso produclivo y el problema estriba tanto en los sindicalos como en los empresarios.

Lo anterior lambién requiere redefinir la injerencia y participación del obrero en los procesos de toma de decisiones y asegurar su conocimiento de los procesos productivos en su conjunto. El obrero debe percibir que su capacidad de trabajo no se limita a su conocimiento técnico, sino también incluye el proceso de la unidad producliva a la que pertenece y la capacidad de ubicación dentro del aparalo productivo nacional. Esto eleva el nivel de conciencia del individuo a un nivel de conciencia de la planta productiva, y eslo implica y requiere una nueva postura del patrón hacia el trabajador.

La nueva relación obrero/palronal implica una nueva aclitud respeclo a la participación, colaboración e injerencia en el proceso productivo del obrero y del patrón, una nueva actilud sobre la conducción, asociación, 
lormas de delimitar y delinir conlradicciones, y también una nueva forma y tamano de cada uno de participar en el valor agregado.

Eslo último es una cuestión de realidad; el monto de la remuneración salarial se encuentra en la base de la identificación con el proceso productivo y en la preocupación del desarrollo de la empresa. Es una concepción románlica requerir del obrero actitudes y sacrilicios si estos no tienen un correspondiente esfuerzo de la conlraparte. Pocas empresas tienen el concepto de incrementos salariales como inversión en la calidad de la producción. Un obrero que-se sienle bien pagado contribuye a las economias internas de la empresa, y, facilmente, por una mejor concentración en la labor productiva y la oplimización de los insumos, puede restituir ampliadamente esa inversión como incremento en la productividad.

En El Salvador, una gran mayoria de empresarios tienen una aclitud defensiva y agresiva hacia la negociación de un contrato colectivo porque no se concibe como oportunidad de compromisos colectivos de los Irabajadores para con la producción. Para mejorar las relaciones obrero/ palronales se requiere más visión sobre la negociación colectiva en el sentido de que ésta se convierte en una concesión de ambas partes; ésta no es únicamente una conseción de salarios y preslaciones sociales, sino también una concesión y compromiso por una mejora de la calidad y la productividad del sindicalo.

Esto conduce a dos aspectos que anteriormente se mencionaron. En primera instancia, a una modernización y reasunción de responsabilidades del Estado con respecto a la relación obrero/ patronal. Además, conduce a la transformación del marco jurídico que regula la actividad obrero/patronal. Se plantea, asi, la necesidad de un nuevo código laboral que debe caracterizarse por una regulación más amplia de esta relación que implique $y$ demande responsabilidades y deberes de ambas partes. En la medida que el Código laboral sea camisa de luerza, no cumple con su función. Los confliclos y huelgas reflejan la inadecuación del marco jurídico/normalivo de la relación, por lo que el código debe representar una nueva relación y regularla.

Simulláneamenle a esla nueva regulación, debe lenerse presente el nuevo papel del Eslado respecto a los confliclos laborales que deben preverse en este nuevo marco jurídico normalivo. Eslo requiere superar posturas inflexibles sobre el tema y la participación de las organizaciones gremiales, laborales y sindicales. Las luerzas politicas vinculadas al movimiento sindical tarde o temprano lendrán que redefinir sus acciones y métodos de trabajo con respecto al movimiento sindical y a la sociedad civil en general. Deben redefinirla ante la nueva realidad que requiere 
garantizar la conslrucción de la nueva sociedad, el desarrollo del mismo sindicalismo y de las mismas organizaciones de izquierda.

\subsection{El desarrollo de una nueva cultura empresarlal}

Uno de los mayores problemas que han existido en el pais es la restricción del concepto de empresa, idenliticándolo con una forma y un tipo de empresa. Se ha concebido como empresa aquella vinculada únicamente a una lorma de propiedad: la propiedad privada individual, y se entiende como ella únicamente a la gran empresa. Esta restricción en el conceplo ha impedido rescatar y forlalecer los amplios benelicios que implica el concepto como la capacidad de responder oportuna y eficientemente ante nuevas necesidades y demandas $y$ la finalidad de la generación de excedenle o ganancia.

Si se redefine el concepto en su amplitud horizontal y vertical, se tiene que éste contempla los distinlos lipos de empresa: asocialiva, individual, estatal, elc., y en un sentido vertical los distintos tamafios y niveles tecnológicos que éslas tienen. La Iranslormación del conceplo de empresa lleva paralelo un cambio del mismo empresario, en la concepción y acción de éste como rentista o buscador de rentas láciles, como la persona que busca oportunistamente ganancias fáciles en momentos corlos o espacios de negocios fáciles con grandes ganancias. En otro extremo se encuentran cierlas empresas asocialivas que ven el la persecución de lucro y excedente como pecado económico y no logran establecer la intima vinculación entre el bienestar de sus socios y la eficiencia de la empresa asocialiva como tal.

Esla visión del empresario debe ser modificada para dar surgimiento a un nuevo concepto de alguien que trata de obtener ganancias sobre la base de su estuerzo vinculado a la actividad producliva que beneficia al país porque genera satisfaclores demandados. Lo anterior implica el desarrollo de una nueva ética empresarial que va en correlación con una nueva ética laboral. Supone la búsqueda y satislacción a través de propiciar el mejor producto, con el mejor servicio, en el momento oportuno y obteniendo la mayor ganancia.

En esle sentido, cuando se habla de una nueva ética empresarial ésta debe ser exlendida a lodas las forma de empresa, valorando la iniciativa y la creatividad individual y estimulando la capacidad de cálculo y disposición al riesgo, ya que ninguna empresa crece si no se toman riesgos calculados. En el crecimiento vertical, en cuanto a la transformación de la ética laboral, se incluye a la micro, pequeña y mediana empresa. La fuente nutriente del desarrollo de la estruclura producliva es la 
micro, pequefia y mediana empresa. Estas por su monto de capital y vinculación a la actividad productiva, son las que permilen la mayor llexibilidad en la adaptación a las nuevas tendencias.

La pequefia y mediana empresa juega un papel clave en la construcción de la nueva plataforma de la estructura productiva. Esto no significa que se debe buscar la desmembración de la gran empresa que es necesaria por las economías de escala fundamentales en la competitividad internacional. Debe entenderse que la estruclura vertical, en su tamano y capacidad tecnológica, puede articular armónicamente las nuevas demandas. No se trala de contraponer las empresas por su tamano ya que cada una tiene un papel ante los nuevos desatios y estructuración productiva. Se debe aprovechar las virtudes y polencialidades de cada una devenientes de las dilerencias de lamafio ante el nuevo escenario mundial.

En su dimensión horizontal las empresas asocialivas tienen un papel imporlante que desempefiar. Debe asumirse una aclitud pragmálica y reconocer que en olras economias coexisten las más variadas formas de producción como el caso de Israel. Debe tenerse claro que lo que se persigue es dinamizar la producoión y para ello debe tenerse una aclilud abierta y llexible a las más variadas formas empresariales. Deben lenerse las más variadas modalidades empresariales que permitan y optimicen la producción y distribución social lo cual debe entenderse de ambos lados. La experiencia de Rusia es reconocer que la propiedad individual es dinamizadora de la actividad productiva, asi lambién se podría relomar la experiencia de Viel-nam en cuanto a la producción de arroz y la propiedad individual.

Muchos errores de ciertos sectores sociales e intelectuales en la apreciación de la actividad empresarial provienen de su desconocimienlo y desvinculación con la actividad productiva la esfera real de la economía, y de los grandes desalios que enfrenta la producción que al requerir respuestas inmedialas genera una determinada aclilud en los empresarios. Se ha dejado al sector empresarial enfrentar el gran desafío histórico de la transformación de la producción. En nuestro país, las universidades y las organizaciones de izquierda otrecen muy poca preocupación al respecto, y casi ninguna alternativa realisla de cara a la articulación de la producción. La sociedad debe nutrirse para su comprensión de los retos que implica para un empresario el responder de inmediato a los requerimientos del mercado para no ser desplazado y perder su inversión. Una cosa es analizar académicamente las actividades productivas desvinculadamente de la acción y el riesgo real y otra es la acción y decisión empresarial que implica loma de decisiones sobre la base del patrimonio personal. 
Es necesario identificar el gran desalio del sector empresarial y la angustia que actualmente enlrentan al percibirse amenazados en sus posibilidades de sobrevivencia por las tendencias inlegracionistas, de liberación de aranceles y unificación mercantil y por la alta competitividad de empresas de otros países. El sector empresarial muy bien identifica que más allá de un problema de lecnología se encueniran también problemas de escalas de producción y conocimiento de mercados que los ubican desfavorablemente en la compelencia internacional. Este conocimiento muy concrelo y específico, les permite valorar la candidez 0 ingenuidad de cierlas organizaciones políticas y académicas.

Una nueva cultura empresarial implica también nuevos y superiores mélodos de administración y trato con el obrero. Significa elevar el nivel cultural-administrativo del empresario con una estructura más cientifica de base en la loma de decisiones. Los empresarios salvadorenos en su gran mayoria, como grupo social, lundamenle su que hacer administrativo en métodos muy personalislas y artesanales. Si se exectua la gran empresa, las cuales son época, el aparato administralivo se ludamenta en la creación de oportunidades familiares del propio empresario, Asímismo se caracteriza por un estilo basado en el conocimiento empirico y en el temor al cambio.

\subsection{La Concertación social como método histórico necesarlo para la formulaclón de politicas.}

La concertación como mélodo general de superar la actual crisis hisIórica de EI Salvador, es aceplada en general por las fuerzas principales de la sociedad. Sin embargo debe tenerse cuidado con la ideologización del término que la identifica con cierta ideología y fuerza política. Esto electivamente está ocurriendo y es un peligro para la misma concertación.

El término concertación liende a provocar dos reacciones dependiendo de la fuerza política. El ser palrimonio de las fuerzas de "izquierda" $\theta$ identificarsele con ellas, y por otro lado, el generar cierto rechazo y estigmatización en las fuerzas de "derecha". Esto es peligroso porque es necesario que exista consenso de que el método para superar la crisis es la concertación. La esligmalización significa que cuando se busque concertar se identifique el mélodo como propuesta parcial de un sector.

La necesidad histórica de la concertación es incuestionable.Toda crisis social se ha resuelto de dos formas; generando nuevas condiciones por medio de la destrucción de uno de los contendientes o por medio de 
la integración de los contendientes, creando una nueva forma de relación. En El Salvador, se tiene un largo periodo de confliclo y guerra que demostró de forma muy práctica que, al menos en la presente crisis y en los próximos anos, no era por el aniquilamiento de uno de los contendienles que se resolveria.

En el periodo anterior la superación de la contradicción lue por la dominación de uno de los contendientes (Hemández Martínez), que origino con el tiempo condiciones que posleriormente en el 48 se superaron. Sin embargo actualmente ninguno de los conlendientes ha podido destruir al olro para crear un nuevo marco y en el fuluro inmediato no se visualizaba otra posibilidad. La resolución del conflicto salvadoreno era una cuestión impostergable para el país dados los cambios internacionales.

Posleriormente a la deslrucción del Japón en la segunda guerra mundial, se desarrolló entre las fuerzas sociales actitudes realistas que se tradujeron y reflejaron en la capacidad de concerlación entre las diferentes fuerzas económicas. Esta capacidad de concertación es el elemento que está en la base y es reconocido como aspecto melodológico intervinienle en el allo desarrollo económico logrado en este país. Ese ejemplo nos orienta a aprovechar las condiciones menlales postbélicas que existen para crear un espacio en el que surga un nuevo método de resolver los problemas.

Cuando la concertación deja de ser económica, es decir, cuando sus costos de oportunidad son superiores para ciertos sectores sociales o para resolver determinados confliclos específicos, se enfrenta un peligro. Cuando una o varias luerzas sociales deja de percibirla como un recurso adecuado. la concertación misma se vuelve un obstáculo para la operalivización de acuerdos o respuestas ante demandas inmediatas. Cuando se quiere concertar lo innecesario y se hace engorroso el procedimiento, la concertación se vuelve un obstáculo para concertar to lundamenlal dejando de tener validez hisiórica como método.

La concertación implica, a la vez, responsabilidad de propuesta de ambas partes en dos sentidos. Por un lado en la responsabilidad misma de proponer, es decir en el esfuerzo real de las partes de investigación y desarrollo de propuestas viables. Por otro lado en sobrepasar el carácter negativo de las propueslas, al defender la propuesla como negación de la del adversario. Las propuestas se realizan sobre el marco de la investigación de la realidad y en función del luturo y no del pasado.

La concertación parte de to que se puede concertar, de los desaflos y problemas que se entrentan conjunlamente, en los puntos coincidentes 0 
los más cercanos; no es posible buscar concerlación en aquello que no se puede o en ese momento no es posible concertar. El método de la concertación implica ir de lo más sencillo a lo más complejo, para ir acumulando acuerdos que permitan generar una masa crítica mínima de consenso que se convierta en un capilal social que no se pueda arriesgar ante la imposibilidad de no concertar los nuevos desatios.

\subsection{La sustentabilldad o sosteniblildad como base general del de- sarrollo socioeconómico.}

La soslenibilidad hace reterencia al carácter general de un modelo de desarrollo en su relación con la base en la cual se sustenta y la estruclura interna que lo mantiene para que pueda perdurar en el liempo, reproduciéndose asimisma y a sus insumos para que no se convierta en un modelo cuya estruclura esté condenada a su fracaso por depredar la base sobre la que se lundamenta, o la Iragilidad de la estructura que lo mantiene.

La base sobre la que se conlorma el modelo, es el gran espacio sobre el que se desarrollan las actividades productivas. Asimismo, esta soslenibilidad hace referencia a la unidad de sus fuerzas sociales y económicas, a la coherencia entre producción y distribución del valor agregado; a la unión de la producción malerial y humana, y de la reproducción de la conciencia por medio del sistema educativo.

Cualquier modelo de desarrollo está condenado a su fracaso al eliminar las externalidades tecnológicas y dinámicas que le hacen competitivo. Si un modelo se fundamenta en agotar las economias o externalidades que le proporciona la naturaleza, es un modelo negativo que alenta contra las posibilidades de la propia nación. Esto mismo ocurre si no se invierle en la reproducción de la fuerza de Irabajo por medio del gasto social.

También, cualquier modelo eslá condenado al tracaso sino se asegura una distribución del produclo que posibilite la reproducción global de la sociedad. Se amenaza su continuidad si no se asegura la eslabilidad politica que permita su desarrollo dentro de cierto equilibrio socioeconómica. En una visión de conjunto e histórica cualquier clase puede ver una concesión actual como una inversion en el fuluro, se puede ceder hoy para asegurar cierta ganancia en el tiempo o en el mafiana. En este sentido, cualquier aparente gasto o consumo social es - realmente una inversión política y económica del fuluro.

Ahora bien, más allá de la denotación polílica y económica de la sostenibilidad se quiere insistir en este apartado en su contenido referen- 
te a la gran casa de todos: el ecosistema. Se parle de concebir la naluraleza como fundamenlo del proceso económico y no algo extraf́o del proceso mismo, fundamento al cual debe nutrir, mantener, desarrollar y cuidar. Esio implica una visión de la relación entre hombre y naluraleza superior a la desarrollada hasta ahora por la economia vulgar. Implica eliminar el concepto de exterioridad de la naluraleza a la sociedad humana y el concepto de antagonismo a la naturaleza, asi como la enajenación o extrañamiento de la sociedad respecto a los propios procesos naturales.

El desarrollo humano está orienlado tarde o lemprano a conformar una sociedad sin anlagonismo con la naluraleza, en intima convivencia e inlegración, en la cual ambos sean partes integrantes y complementarias de un sólo ser global La sociedad humana deberá en un futuro cumplir la tunción de ser conclencia y administradora de la naturaleza en un concepto de unidad entre sociedad y naluraleza. Lo anterior no se fundamenta en una visión romántica de la naturaleza sino en una necesidad de sobrevivencia de la propia sociedad humana. No se está anle un conceplo romántico sino anle la necesidad de una plataforma económica que permita su sustenlo y la existencia humana como tal.

Para el caso, se puede tomar la experiencia polaca, que, debido al desarrollo industrial sin tomar en cuenta el ecosistema, to ha deteriorado a puntos alarmantes. En este pais, un alto porcentaje del territorio está declarado como dafino y perjudicial para la vida humana. En esle caso, las mismas fuerzas han llegado al consenso que debe ser el ecodesarrollo la plataforma y el concepto general dentro del cual se viabilice el concepto de desarrollo económico y social.

"En Polonia, la oposición liderada por Solidaridad y el gobierno, acordaron, en una mesa redonda celebrada en los meses de febrero-abril de 1989, considerar el 'ecodesarrollo' como un concepto de primer orden para fomenlar el desarrollo socio-económico del pais, y de acuerdo con esto revisar los planes económicos y espaciales y especialmente to que se refiere a la industria de la mineria y el acero".

Este eje de ecodesarrollo o sostenibilidad de cualquier modelo de desarrollo no. puede_ser. un anexo de cualquier plataforma política para ponerse a moda con los nuevos conceptos. Tampoco puede ser un punto de discusión entre distintas fuerzas políticas. Tiene más bien quẹ ser el tundarnento presente en toda platatorma o modelo de desarrollo de cualquier tendencla polttica. En esle sentido la sostenibilidad no puede ser punto final de una propuesta, tal como acá se ha ubicado, sino más bien, el primer punto de cualquier plataforma. En esle caso, el colocarla al tinal es por recurso melodológico de exposición, para 
redimensionar todos los anteriores aspectos en función de este contenido crucial y fundamental. No se puede reivindicar el concepto de sostenibilidad para si mismo o para una fuerza particular y no asegurar congruencia con la asignación de recursos presupuestarios, con lodos los elementos planteados y las realidades económicas mundiales. EI problema no es que discursivamente se reinvidique como moda, como compelencia o propaganda, sino el viabilizar congruentemente tales planteamienlos con propuestas concretas.

Debe combatirse la vulgarización o mediocrización del concepto de sostenibilidad, y rehuirse su discusión partidaria en el sentido de que sea patrimonio de una luerza política o reivindicarlo como una luerza política propia. La sostenibilidad y desarrollo, si se comprenden en su magnitud, deben ser propueslas equibalanceadas con la paz como valor y reivindicación nacional. En este sentido se entiende que la concertación es el método general y la sostenibilidad la plataforma general de toda propuesta.

\section{Conclusión.}

La búsqueda de la agenda económica y la conformación de una estrategia nacional de desarrollo es una responsabilidad de todas las fuerzas sociales. Se debe partir de lo consensuable o concertable, como responsabilidad para asegurar la paz y el desarrollo nacional. Sin embargo, las propueslas, dado el momento aclual, son de urgenle necesidad. Las caracteristicas de las propuestas de la agenda económica, además de su concertabilidad, deben reunir como requisilo la congruencia de la lemática en si misma y la consistencia con la realidad y no con principios o dogmas preestablecidos.

En este senlido, la conciencia en todas las fuerzas sociales sobre la profundidad y la envergadura de los cambios mundiales y de los grandes desafios e implicaciones de la transiormación tecnológica y económica mundial se conslituyen en un requisilo de gran valor para enfrentar los retos y unir a los dislintos sectores en el luturo. Sin embargo, en la actualidad no existe conciencia en nuestra inteleclualidad y dirigencia política sobre la dimensión de estos cambios y las implicaciones para El Salvador.

A modo de conclusión, es necesario insistir nuevamente sobre las tareas de mayor relevancia devenientes de la exposición:

a. La conciencia del cambio mundial. La comprensión del hundimiento de un viejo orden mundial e internacional y el surgimienlo, tarde o tem- 
prano, de uno nuevo, que está afectando decididamente la base sobre la cual se erigiria cualquier posibilidad de desarrollo del país, se constituye en el marco global sobre el cual se tiene que planlear cualquier estrategia viable de cualquier signo. La conciencia de este cambio mundial implica que, más allá de cualquier interprelación de sus causas y formas, es necesario que se identifique la envergadura de los cambios y las consecuencias para el siglo XXI que tienen para nuestro país.

La conciencia sobre este cambio mundial es determinanle para el plantemiento de las estrategias de desarrollo. La concepción del nuevo orden económico mundial, o de sus posibilidades de realización o surgimiento, claramente condicionarán la conformación de la estralegia de desarrollo nacional. Por hoy, más que una discusión conceptual de este nuevo orden, es necesario al menos lograr la conciencia mínima de la finalización de un bloque hislórico y de una rearticulación de nuestro pais ante este nuevo orden.

Lo mundial, sin embargo, no debe concebirse como lo externo. Lo mundial es la lolalidad de la cual formamos parte, independientemente del sistema económico que exista en el país. Debe superarse la perspectiva arcaica de la relación entre lo externo e interno subyacente en muchos sectores de Latinoamérica.

b. La estrategia nacional de desarrollo. Paralelamente se entrenta la realidad y la necesidad de la reinserción o reubicación, que dentro de una estrategia nacional de desarrollo es planteada como una reinserción conveniente, es decir, aquella que permila de forma dinámica participar justamente del produclo mundial.

En esla perspectiva, es necesario fomentar la discusión, la investigación sobre las estrategias nacionales, regionales o sectoriales, convirtiéndose en el tema de aclualidad del quehacer investigativo y científico en todos los centros de actividad inlelectual y política. Esle debe ser también uno de los temas cotidianos de la discusión política.

En este punto se deben superar los estilos líricos, nihilistas o de planteamienlos de mera negación del contendiente y generalistas. No es posible en este periodo de nuestra historia aceptar propueslas generales con fórmulas globales o meramente declaraciones de principios. Los dos principales actores polílicos de la coyuntura, a la fecha no plantean estralegias nacionales de desarrollo de cara a esta nueva situación del mercado mundial. Esto hace necesario fomentar una labor de investigación y propuesta a los más diversos niveles sobre los diferentes componentes de una estrategia nacional de desarrollo. En esta línea, lodo esfuerzo, por pequefio que sea, es necesario y válido. Lo que es intras- 
cendente en esta perspectiva es continuar con la relórica de declaraciones de principios que impiden avanzar en el lema

c. La construcción de una plataforma más amplia y elevada de discusión. Para ser realistas no debe esperarse una concertación formal de lodos los puntos sobre el tema de estralegia nacional. Más bien lo que se debe buscar es la consirucción de una platalorma más amplia y elevada a nivel científico y operativa de la discusión al respecto. Es decir, es necesario buscar una plalaforma para lodos los agentes políticos e intelectuales que permila generar nuevas diferencias, pero basadas en un nivel más elevado de propuesta.

d. El papel de las universidades. Las universidades en esle aspeclo y tareas pueden y deben asumir un papel importanle en la generación de una discusión permanente que enfrente el desatio orientado al siglo XXI en cuanto a las dilerentes posibilidades de desarrollo. Es necesario que promuevan la discusión permanente a todos los niveles sobre los temas apuntados y que hagan esluerzos por reestructurar la carrera de economia en su orientación, centrándola en la transtormación de la oferta y no en sólo en el manejo de la demanda. Debe dotarse a los futuros profesionales de un conocimiento más concreto de la eslera real de la economía nacional y de instrumentos para transtormar el aparato productivo dentro de las nuevas realidades mundiales.

e. El papel estrategico de la educación. Relevar especialmente el papel de la revolución educativa dentro de una estrategia económica, puede parecer al economisla tradicional desubicado. Esta relevancia proviene de una convicción que a la vez es originada en la compresión de la profunda unidad entre producción y educación, entre reproducción material y social. Esla compresión de unidad de los procesos sociales es de los produclos más elevados del desarrollo actual de las Ciencias Sociales.

La experiencia para el avance continuado de las sociedades también puede provenir de analizar los grandes períodos de regresión histórica. Estos periodos se han provocado cuando la vieja estructura social se ha hundido y no hay una nueva que la supere y se imponga. La historia no es lineal. Grandes sociedades se veian en la antigüedad relegadas a períodos supuestamente ya superados cuando no se lograba constiluir una clase o bloque dirigente que asumiera como suyo, elevándose por encima de sus intereses particulares, los intereses de loda la sociedad, para que la unilicara y la hiciera avanzar hacia períodos superiores.

Esla forma de comportarse de sociedades particulares fue normal hasta la era de los grandes descubrimienlos, donde el mundo en sus 
partes fundamentales quedó integrado y se dió inicio a la historia económica mundial como unidad. A partir de esle momento, diferentes formas de producción coexisten, pero con un signilicado y papel funcional, subsumido, dentro de la estructura de producción moderna, dentro de una gran jerarquia, así como de dilerentes niveles tecnológicos. En la actualidad, cuando sociedades particulares no entrentan los grandes desalios y no logran superar sus crisis históricas se ven relegadas y degradadas en su ubicación a niveles y posiciones más superfluas a la dinámica de la economía mundial, constituyéndose en el mundo de la intormalidad y de la prescindibilidad económica e hislórica mundial.

\section{REFERENCIAS BIBLIOGRAFICAS}

ASI Revisla Industria N2 37 Oct-Dic 1991. San Salvador

Banco Mundial: Informe sobre el Desarrollo Mundial 1991.

BID. Ciencia y Tecnología en América Latina. Progreso Económico y Social en América Latina. Informe 1988.

CEPAL/PNUD: Reconversión Industria en Centroamérica: Diagnóstico e Identificación de Necesidades de Cooperación Técnica. Santiago de Chile Octubre 1990.

CEPALUNESCO Educación y Conocimiento: Eje de la Trasformación productiva con equidad, Santiago de Chile, 1992.

F. Fajnzyber, "Sobre la impostergable transformación productiva de A.L." Pensamiento lberoamericano No 16, 1989.

FUSADES Caracterización Socioeconómica de la población de El Salvador, Análisis Descriptivo. San Salvador 1989.

PNUD, Human Development Report 1991. Oxford, New York.

Portes A. y Kincaid A.D. (compiladores). Teorias del Desarrollo Nacional. San José, C.R.: EDUCA , 1991.

SELA, La economia Mundial y El desarrollo de América Latina y el Caribe, Edi. Nueva Sociedad. Caracas 1988. 